\title{
A macroporous bioreactor super activated by the recombinant human transforming growth factor- $\beta_{3}$
}

\author{
Ugo Ripamonti ${ }^{1}$, June Teare ${ }^{1}$ and Carlo Ferretti ${ }^{1,2}$ \\ ${ }^{1}$ Bone Research Unit, Faculty of Health Sciences, School of Physiology, Medical Research Council/University of the Witwatersrand, Johannesburg, South Africa \\ ${ }^{2}$ Division of Maxillofacial and Oral Surgery, University of the Witwatersrand, Johannesburg, South Africa
}

Edited by:

Vesa Kaartinen, University of

Michigan, USA

Reviewed by:

Yuji Mishina, University of Michigan, USA

Franz E. Weber, University Hospital, Switzerland

Peter X. Ma, University of Michigan, USA

\section{*Correspondence:}

Ugo Ripamonti, Bone Research Unit, Faculty of Health Sciences, School of Physiology, Medical Research Council/University of the Witwatersrand, 2193 Parktown Johannesburg, South Africa. e-mail: ugo.ripamonti@wits.ac.za

Macroporous single phase hydroxyapatite $(\mathrm{HA})$ and biphasic $\mathrm{HA} / \beta$-tricalcium phosphate with $33 \%$ post-sinter hydroxyapatite (HA/ $\beta$-TCP) were combined with 25 or $125 \mu \mathrm{g}$ recombinant human transforming growth factor- $\beta 3\left(\mathrm{hTGF}-\beta_{3}\right)$ to engineer a super activated bioreactor implanted in orthotopic calvarial and heterotopic rectus abdominis muscle sites and harvested on day 30 and 90 . Coral-derived calcium carbonate fully converted (100\%) and partially converted to 5 and $13 \%$ hydroxyapatite/calcium carbonate ( 5 and $13 \% \mathrm{HA} / \mathrm{CC}$ ) pre-loaded with 125 and $250 \mu \mathrm{g}$ hTGF- $\beta_{3}$, and 1:5 and 5:1 binary applications of hTGF- $\beta_{3}$ : hOP-1 by weight, were implanted in the rectus abdominis and harvested on day 20 and 30 , respectively, to monitor spatial/temporal morphogenesis by high doses of hTGF- $\beta_{3}$. Bone formation was assessed on decalcified paraffin-embedded sections by measuring the fractional volume of newly formed bone. On day 30 and 90, single phase HA implants showed greater amounts of bone when compared to biphasic specimens; 5 and $13 \%$ HA/CC pre-loaded with 125 and $250 \mu \mathrm{g}$ hTGF- $\beta_{3}$ showed substantial induction of bone formation; $250 \mu \mathrm{g} \mathrm{hTGF}-\beta_{3}$ induced as yet unreported massive induction of bone formation as early as 20 days prominently outside the profile of the macroporous constructs. The induction of bone formation is controlled by the implanted ratio of the recombinant morphogens, i.e., the 1:5 hTGF- $\beta_{3}:$ hOP-1 ratio by weight was greater than the inverse ratio. The unprecedented tissue induction by single doses of $250 \mu \mathrm{g} \mathrm{hTGF-} \beta_{3}$ resulting in rapid bone morphogenesis of vast mineralized ossicles with multiple trabeculations surfaced by contiguous secreting osteoblasts is the novel molecular and morphological frontier for the induction of bone formation in clinical contexts.

Keywords: osteogenic proteins, transforming growth factor- $\beta_{3}$, biomimetic matrices, coral-derived macroporous constructs

\section{INTRODUCTION}

Nature relies on common but limited conserved molecular mechanisms tailored to provide the emergence of specialized tissues and organs. The bone morphogenetic/osteogenic proteins (BMPs/OPs), members of the transforming growth factor- $\beta$ (TGF- $\beta$ ) supergene family (Wozney et al., 1988), are an elegant example of Nature's parsimony in programming multiple specialized functions deploying several molecular isoforms with minor variation in amino acid motifs within highly conserved carboxy-terminal regions (Reddi, 1997, 2000; Miyazono et al., 2001; Ripamonti, 2006a; Lander, 2007).

BMPs/OPs singly induce de novo endochondral bone formation in extraskeletal heterotopic sites of rodents as a recapitulation of embryonic development (Reddi, 1994, 1998, 2000; Ripamonti, 2006a). The molecular cloning of the BMPs/OPs (Wozney et al., 1988; Özkaynak et al., 1990) and the results obtained in numerous pre-clinical studies in mammalian species including non-human primates (Reddi, 2000; Ripamonti, 2004, 2006a) have prematurely convinced molecular biologists, tissue engineers, and skeletal reconstructionists alike to believe that a single recombinant human bone morphogenetic protein would result in clinically acceptable tissue induction and morphogenesis (Friedlaender et al., 2001; Govender et al., 2002).

This theoretical potential has not been translated to acceptable results in clinical contexts. Clinical trials of craniofacial and orthopedic applications such as mandibular reconstruction and sinus-lift operations have indicated that supra physiological doses of a single recombinant human protein are needed to induce often unacceptable tissue induction whilst incurring significant costs without equivalence to autogenous bone grafts (Ripamonti et al., 2006, 2007a, 2009a; Garrison et al., 2007; Mussano et al., 2007).

The need for alternatives to the recombinant human BMPs/OPs is now felt more acutely following the reported complications and performance failure associated with the clinical use of recombinant hBMP-2 (Carragee et al., 2011a,b). Additional concerns are the apparent association of high doses of hBMP-2 with malignancies (Fauber, 2011a). Because of the often substandard regeneration of clinical defects implanted with hBMPs/OPs, similar if not inferior to autogenous bone grafts (Garrison et al., 2007; Mussano et al., 2007; Ripamonti et al., 2007a), we now need to finally ask the provocative question: are the bone morphogenetic proteins the only initiators of the induction of bone formation in clinical contexts? 
The osteoinductive prerogative, originally solely assigned to naturally derived and recombinantly produced BMPs/OPs, has been extended to the three mammalian TGF- $\beta$ isoforms themselves. The three mammalian TGF- $\beta$ isoforms are determinant of a prominent endochondral osteoinductivity in heterotopic intramuscular sites of the non-human primate Papio ursinus (Ripamonti et al., 1997, 2000a, 2008; Ripamonti and Roden, 2010). Using the insoluble collagenous bone matrix as carrier, the TGF- $\beta_{3}$ isoform induces rapid and substantial endochondral bone formation in the rectus abdominis muscle of $P$. ursinus (Ripamonti et al., 2008).

We now describe the induction of bone formation by a variety of macroporous calcium phosphate-based constructs implanted in heterotopic intramuscular rectus abdominis and orthotopic calvarial sites of $P$. ursinus to engineer a super activated bone bioreactor by the hTGF- $\beta_{3}$ isoform for the rapid induction of bone formation in pre-clinical and clinical contexts. We further report that the ratio by weight of the binary application of hTGF- $\beta_{3}$ and hOP- 1 is a critical parameter that controls the synergistic induction of bone formation. The reported unprecedented tissue induction and morphogenesis by single doses of $250 \mu \mathrm{g}$ hTGF- $\beta_{3}$ indicate the novel molecular and morphological frontier for the induction of bone formation in clinical contexts.

\section{MATERIALS AND METHODS PRIMATES MODELS FOR TISSUE INDUCTION AND MORPHOGENESIS}

Eight clinically healthy adult Chacma baboons $P$. ursinus were selected from the non-human primate colony of the University of the Witwatersrand, Johannesburg. Selection criteria, diet, and housing conditions were as described (Ripamonti, 1991a,b). The adult non-human primate $P$. ursinus is ideally suited for the study of comparative bone physiology and repair with relevance to humans (Schnitzler et al., 1993; Ripamonti et al., 2001). Research protocols were approved by the Animal Ethics Screening Committee of the University and conducted according to the Guidelines for the Care and Use of Experimental Animals prepared by the University and in compliance with the National Code for Animals Use in Research, Education, and Diagnosis in South Africa (Public Services Department, 1990).

\section{OSTEOGENIC SOLUBLE MOLECULAR SIGNALS}

Recombinant human transforming growth factor- $\beta_{3}$ (hTGF- $\beta_{3}$ ) and recombinant human osteogenic protein-1 (hOP-1) were obtained from Novartis AG (Basel, Switzerland) and Creative Biomolecules/Stryker Biotech (Hopkinton, MA, USA), respectively. Stock solutions of hTGF- $\beta_{3}$ were prepared in $20 \%$ ethanol $100 \mathrm{mM}$ acetic acid, $\mathrm{pH} 4.5$, to a final volume of $200 \mu \mathrm{l}$ with 25 and $125 \mu \mathrm{g}$ hTGF- $\beta_{3}$ dispensed by micro-pipetting onto the macroporous constructs. Stock solutions of hOP-1 were prepared in $5 \mathrm{mM}$ hydrochloric acid to a final concentration of $0.625 \mu \mathrm{g} / \mu \mathrm{l}$ and applied to selected macroporous devices as described above. For the binary application studies, $5 \mu \mathrm{g}$ TGF- $\beta_{3}$ were added to $25 \mu \mathrm{g}$ hOP-1 (1:5 ratio) and made up to a final volume of $200 \mu$ l. An inverse binary combination (5:1, i.e., $25 \mu \mathrm{g}$ TGF- $\beta_{3}$ : $5 \mu \mathrm{g}$ hOP-1) was prepared and applied to selected macroporous devices.

\section{DESCRIPTION AND SPECIFICATION OF CALCIUM PHOSPHATE-BASED MACROPOROUS CONSTRUCTS FOR HETEROTOPIC AND ORTHOTOPIC IMPLANTATION}

\section{Single phase hydroxyapatite constructs}

Single phase hydroxyapatites with a calcium-to-phosphorus molar ratio of 1.67 were prepared via a solid state reaction between Merck tricalcium phosphate and Univar calcium hydroxyapatite at $1000^{\circ} \mathrm{C}$ (Ripamonti et al., 2007b). For all the macroporous constructs, macro pores were formed by the inclusion of stearic acid spheres $0.7-1.0 \mathrm{~mm}$ in diameter with the bioceramic powder being pressed, and melted out during sintering, leaving interconnected open macro pores with a series of repetitive concavities throughout the specimens with defined radii of curvatures and diameters ranging from 700 to $1400 \mu \mathrm{m}$ (Ripamonti et al., 2007b). The micro porosity of the specimens ranged from $40 \%$ (single phase hydroxyapatite) to $36 \%$ (biphasic hydroxyapatite/ $\beta$-tricalcium phosphate; Ripamonti et al., 2007b).

\section{Hydroxyapatite/ $\beta$-tricalcium phosphate macroporous constructs}

Hydroxyapatite and $\beta$-tricalcium phosphate powders were combined to form batches with pre-sinter HA $/ \beta$-TCP content ratio (wt \%) of 50/50. Macroporous samples were pressed from powders containing stearic acid spheres of between 0.7 and $1.0 \mathrm{~mm}$ in diameter to construct porous disks $25 \mathrm{~mm}$ in diameter by $4 \mathrm{~mm}$ in thickness for orthotopic calvarial and heterotopic intramuscular implantation (Ripamonti et al., 2007b). Samples were sintered pressureless in air for $1 \mathrm{~h}$ at $1020^{\circ} \mathrm{C}$; sintering resulted in postsinter constructs of $33.3 \%$ hydroxyapatite/ $\beta$-tricalcium phosphate (HA/ $\beta$-TCP; Ripamonti et al., 2007b). The post-sinter HA/ $\beta$-TCP phase content ratios of the biphasic bioceramic constructs were determined by the semi quantitative XRD-based Chung (1974) method. The measurements revealed a decrease in HA intensity relative to the known pre-sinter HA contents, with an associated increase in $\beta$-TCP intensity (Nilen and Richter, 2008).

\section{Coral-derived macroporous calcium carbonate/calcium phosphate constructs}

Three macroporous hydroxyapatite replicas of the calcium carbonate exoskeletal macrostructure of the sea coral of the genus Goniopora were prepared by hydrothermal chemical exchange with phosphate to the protocol specification (Interpore International, Irvine, CA, USA; Ripamonti, 1991a; Ripamonti et al., 1992, 1993; Shors, 1999). Calcium carbonate coral-derived constructs were subjected to complete conversion to hydroxyapatite (100\% HA); limited conversion to hydroxyapatite resulted in calcium carbonate constructs with 5 and 13\% hydroxyapatitecoating, respectively, and designated as 5 and $13 \%$ calcium carbonate/hydroxyapatite constructs ( 5 and 13\% HA/CC; Ripamonti et al., 1992, 2009b).

For orthotopic calvarial implantation, single phase hydroxyapatite (single phase HA) and biphasic hydroxyapatite $/ \beta$-tricalcium phosphate (HA/ $\beta$-TCP) constructs (Council for Scientific and Industrial Research, Materials Science and Manufacturing, Pretoria, South Africa) were sintered into macroporous disks, $25 \mathrm{~mm}$ in diameter by $4 \mathrm{~mm}$ in thickness (Ripamonti et al., 2007b); the contra-lateral calvarial implantation design for the allocation of the treatment variables is illustrated in Figure 1A. 


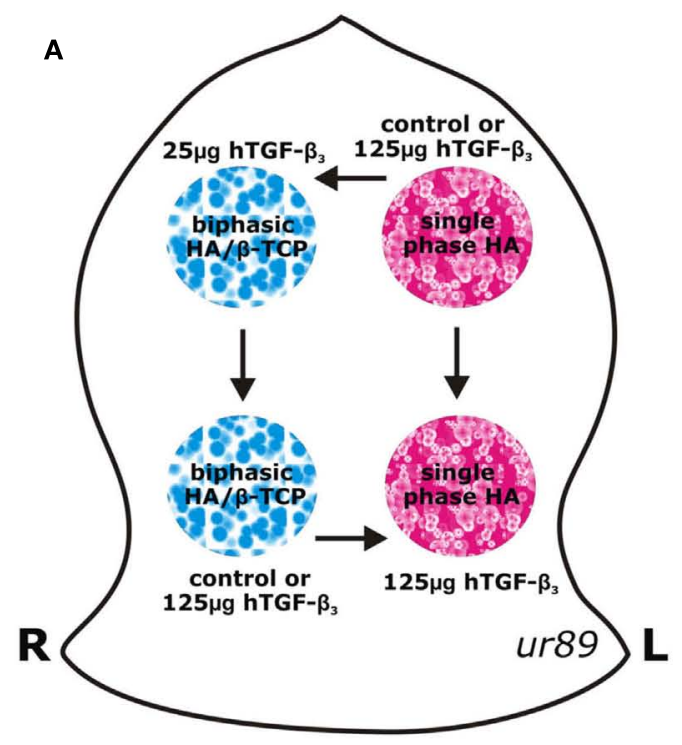

B

$25 \mu \mathrm{g} \mathrm{hTGF}-\beta_{3} \quad 125 \mu \mathrm{g} \mathrm{hTGF}-\beta_{3}$

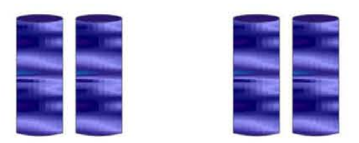

biphasic HA/ $\beta-T C P$

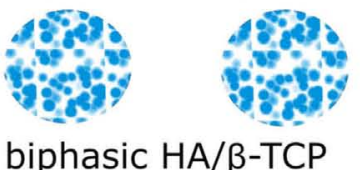

biphasic $\mathrm{HA} / \beta-\mathrm{TCP}$

$125 \mu \mathrm{g}$ hTGF- $\beta_{3} \quad 25 \mu \mathrm{g} \mathrm{hTGF}-\beta_{3}$

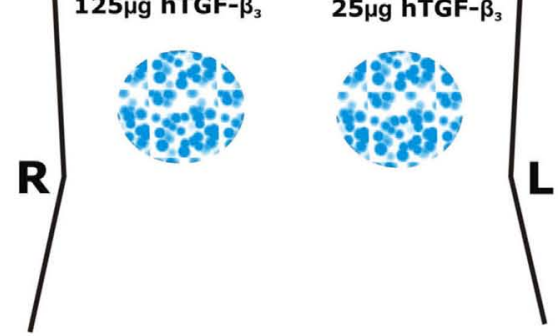

。
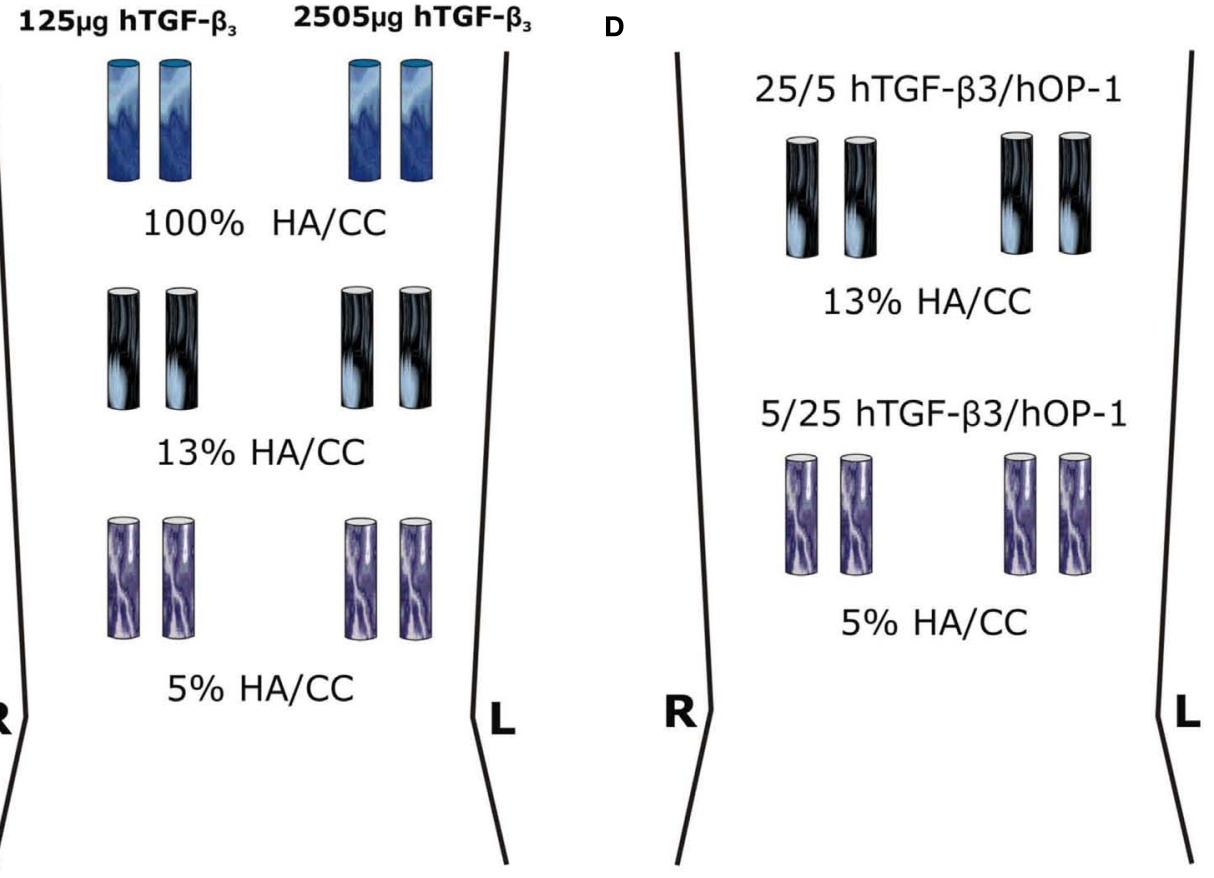

FIGURE 1 | Surgical models and implantation designs in the Chacma baboons Papio ursinus for tissue induction and morphogenesis by calcium phosphate-based macroporous constructs implanted in orthotopic calvarial and heterotopic rectus abdominis intramuscular sites. (A) A calvarial Latin square block design resulted in the rotational allocation of macroporous disks of single phase (single phase $\mathrm{HA}$ ) and biphasic hydroxyapatite/ $\beta$-tricalcium phosphate (HA/ $\beta$-TCP) constructs solo or pre-loaded with 25 and $125 \mu \mathrm{g}$ human transforming growth factor- $\beta_{3}\left(\right.$ hTGF- $\beta_{3}$ ) within a total of 24 calvarial defects in four animals with a balanced distribution between anterior and posterior regions of the calvaria (Ripamonti, 2006a; Ripamonti et al., 2007b). (B-D)

Heterotopic intramuscular rectus abdominis model and implantation

designs in eight adult Chacma baboons P. ursinus. (B) Heterotopic implantation of 4 disks $25 \mathrm{~mm}$ in diameter $3.5 / 4 \mathrm{~mm}$ in thickness and 4 cylinders $12 \mathrm{~mm}$ in diameter in $4 P$. ursinus for a total of 32 specimens in the rectus abdominis muscle. (C) Intramuscular rectus abdominis implantation of 12 coral-derived calcium carbonate-based macroporous constructs fully converted to hydroxyapatite (100\% HA/CC), and partially converted to 5 and $13 \%$ hydroxyapatite (5 and 13\% HA/CC) pre-loaded with 125 and $250 \mu \mathrm{g}$ hTGF- $\beta_{3}$ implanted in two adult $P$. ursinus and harvested on day 20. (D) Intramuscular rectus abdominis implantation in two adult $P$. ursinus of $413 \%$ and $45 \%$ partially converted HA/CC constructs pre-loaded with binary applications of hTGF- $\beta_{3}$ : hOP-1 at 5:1 and $1: 5$ ratios and harvested on day 30 . 
For heterotopic rectus abdominis implantation, HA/ $\beta$-TCP samples were sintered as macroporous constructs of disks $25 \mathrm{~mm}$ in diameter by $3.5 / 4 \mathrm{~mm}$ in thickness, and as cylindrical rods $9 \mathrm{~mm}$ in diameter by $20 \mathrm{~mm}$ in length (Figure 1B). Coral-derived calcium carbonate/hydroxyapatite constructs 5 and 13\% conversion to hydroxyapatite (Ripamonti et al., 1992, 2009b) as well as fully converted specimens were also implanted in the rectus abdominis muscle of the baboon (Figures 1C,D).

The heterotopic rectus abdominis and orthotopic calvarial models of tissue induction and morphogenesis by osteoinductive biomimetic matrices have been described in detail (Ripamonti, 1991a,b, 2006a; Ripamonti et al., 1992, 1993, 2007b, 2009b). Biomimetic matrices for orthotopic implantation (in four animals) were combined with doses of hTGF$\beta_{3}$ (Figure 1A). Single phase HA or biphasic HA/ $\beta$-TCP disks were treated with 0,25 , and $125 \mu \mathrm{g}$ hTGF- $\beta_{3}$. A total of 16 disks were implanted, i.e., four per animal as shown in Figure 1A.

A total of 32 biomimetic matrices for heterotopic implantation (in four animals, initially) were combined with 25 and $125 \mu \mathrm{g}$ hTGF- $\beta_{3}$ (Figure 1B). After preliminary morphological results of biphasic HA/ $\beta$-TCP implants, samples of fully converted coral-derived CC/HA and partially converted 5 and 13\% CC/HA constructs were combined with high doses of hTGF- $\beta_{3}$ as shown in Figure 1C, and implanted heterotopically in an additional two animals. A total of 16 heterotopic binary applications of hTGF- $\beta_{3}$ and hOP-1 were applied at ratios of $1: 5$ and $5: 1$ by weight and implanted in the rectus abdominis muscle of an additional two P. ursinus animals (Figure 1D). Previous data reporting macroporous devices implanted without morphogens were used as controls (Ripamonti, 1991a; Ripamonti et al., 1992, 1993, 1999, 2007b, 2009b).

\section{Tissue harvest, histology, and histomorphometry}

Thirty and 90 days after implantation of orthotopic calvarial and heterotopic intramuscular biomimetic matrices, anesthetized animals were euthanized with an intravenous overdose of sodium pentobarbitone. Anesthetized animals were subjected to bilateral carotid perfusion with buffered saline followed by $10 \%$ buffered formalin and harvesting of specimens with surrounding calvaria as described (Ripamonti et al., 1992, 1993, 1999, 2007b, 2009b; Ripamonti, 2006a). The four additional P. ursinus animals, implanted with coral-derived CC/HA combinations, were euthanized on day 20 and 30 , respectively.

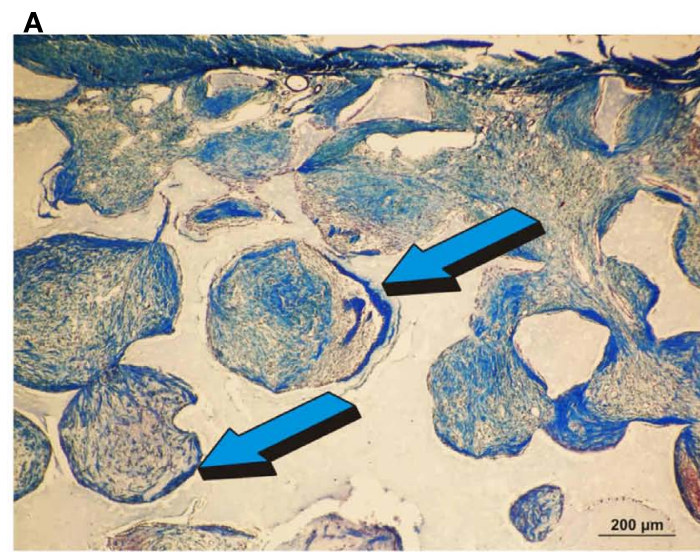

C

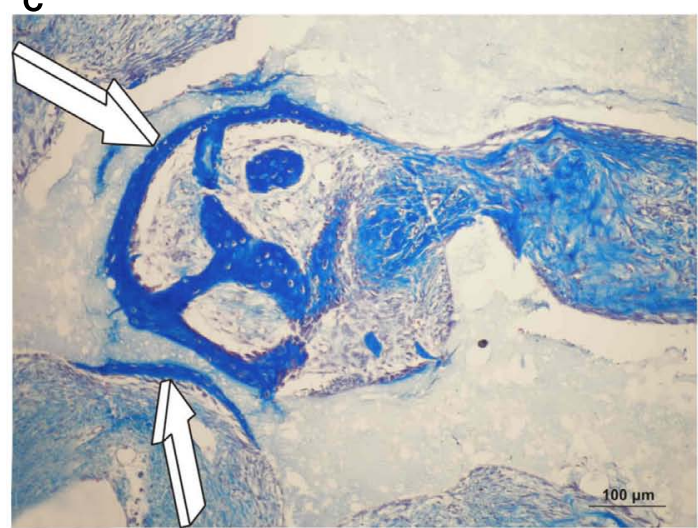

FIGURE 2 | Orthotopic single phase hydroxyapatite constructs harvested on day 30 and the induction of bone differentiation by 25 and $125 \mu \mathrm{g}$ recombinant human transforming growth factor- $\beta 3$ $\left(\mathbf{h T G F}-\boldsymbol{\beta}_{3}\right)$. (A,B) Low and high power views of the induction of bone formation within concavities of the macroporous spaces (blue arrow) as

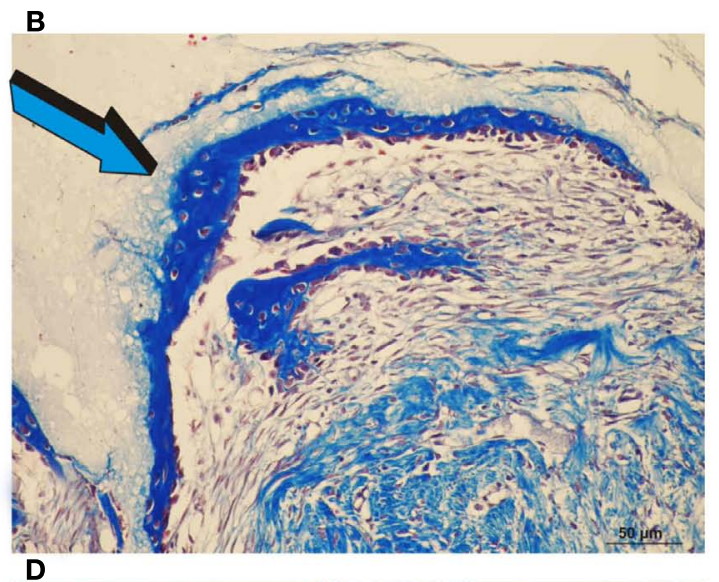

D

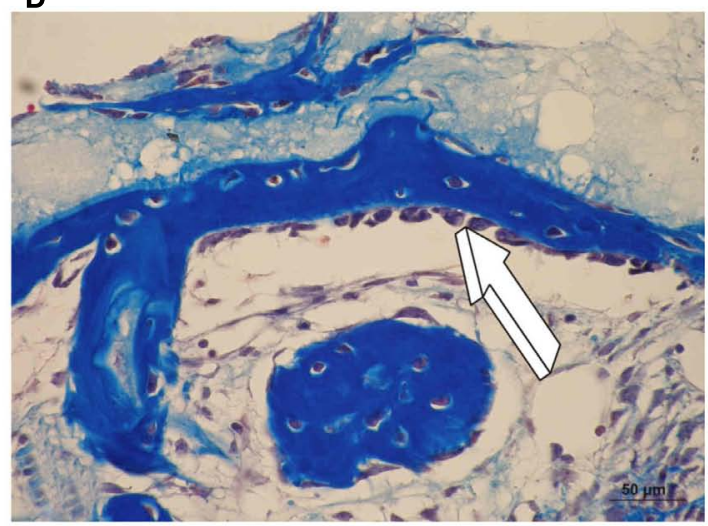

initiated by $25 \mu \mathrm{g} \mathrm{hTGF}-\beta_{3}$ on day 30 . (C) Induction of bone formation ( $w$ hite arrows) by $125 \mu \mathrm{g} \mathrm{hTGF}-\beta_{3}$ within the macroporous spaces of a single phase HA construct. (D) Hypercellular osteoblastic activity of the newly formed bone (white arrow) tightly attached to the single phase HA substratum. 
Calvarial specimen blocks were cut along the sagittal onethird of the implanted defects, and further fixed in 10\% buffered formalin; orthotopic and heterotopic blocks were decalcified in a formic and hydrochloric acid solution and processed for paraffin embedding. Serial sections cut at $4 \mu \mathrm{m}$ were stained by the Goldner's trichrome method and examined using an Olympus Provis AX70 Research Microscope (Olympus Optical Company, Tokyo, Japan). Using the point-counting technique (Parfitt, 1983), a calibrated Zeiss integration Platte II with 100 lattice points was used to calculate the fractional volume of each of the following histological components: newly formed bone, fibrovascular tissue (including marrow) and the implanted scaffold (Ripamonti et al., 1992, 1993, 1999, 2001, 2007b, 2009b).

Sections were analyzed at a magnification of $4 \times$ with the Zeiss graticule superimposed over five sources selected for Histomorphometry (Ripamonti, 1991a,b, Ripamonti et al., 1992, 1993, 1999, 2001, 2007b, 2009b). Each source represented a field of $7.84 \mathrm{~mm}^{2}$. Morphometry was performed on two calvarial sections per implant, approximately $0.5-3 \mathrm{~mm}$ apart. Transversely cut decalcified heterotopic specimens were analyzed by superimposing the Zeiss graticule over two sources of two serial sections per specimens as described (Ripamonti, 1991a,b; Ripamonti et al., 1992, 1993, 1999, 2001, 2007b, 2009b). The calculations were expressed in mean percentage values. Using GraphPad Prism ${ }^{\mathrm{TM}}$ computer software for statistical analyses (GraphPad Software Inc., San Diego, CA, USA), the mean values, standard deviation and standard error were calculated and bar graphs plotted (Ripamonti et al., 2009b). p-Values were calculated by one-way analysis of variance (ANOVA). Significant differences were detected by Bonferroni's and Dunnet's multiple comparison tests (Ripamonti et al., 2009b).

\section{RESULTS}

\section{HISTOLOGY AND HISTOMORPHOMETRY}

\section{Orthotopic implants: single phase HA implants - $\mathbf{3 0}$ and $\mathbf{9 0}$ days}

Untreated single phase HA orthotopic specimens showed lack of bone formation with minimal bone by conduction at the calvarial interfaces $(<2 \%)$. Specimens treated with 25 and $125 \mu \mathrm{g}$ hTGF- $\beta_{3}$ showed limited induction of bone formation by day 30 (Figures 2 and 3); the induction of bone, though minimal on day 30 , had occurred along concavities of the macroporous spaces (Figure 2). By day 90, control specimens showed the induction of bone formation across the macroporous constructs $(21.66 \pm 0.60 \%)$ though preferentially endocranially with minimal bone formation pericranially below the temporalis muscle (Figures 4A,B). On day 90, single phase HA pre-loaded with 25 and $125 \mu \mathrm{g} \mathrm{hTGF}-\beta_{3}$ resulted in a dose-dependent increase of bone induction ( $46.29 \pm 6.3$ vs. $74.40 \pm 3.4 \%$ ), respectively (Figures 4 and 5 ). A significant difference ( $p<0.01$ ), as detected by Dunnet's multiple comparison test, was noted for control vs. single phase HA pre-loaded with $125 \mu \mathrm{g}$ hTGF- $\beta_{3}$ (Figure 5). Newly induced bone by the hTGF- $\beta_{3}$ isoform was characterized by numerous contiguous rows of well rounded osteoblasts surfacing the newly induced bone within the macroporous spaces of the implanted substrata (Figures 4E,F).

\section{Orthotopic implants: biphasic HA/ $\beta$-TCP-HA 33\% implants - 30 and 90 days}

Control specimens of biphasic HA/ $\beta$-TCP showed albeit minimal (Figure 3), the induction of bone formation classically forming within concavities of the macroporous substratum (Figure 6). Newly formed bone protruded within the macroporous spaces covered by numerous contiguous osteoblasts (Figure 6B). On day 30, scattered islands of newly

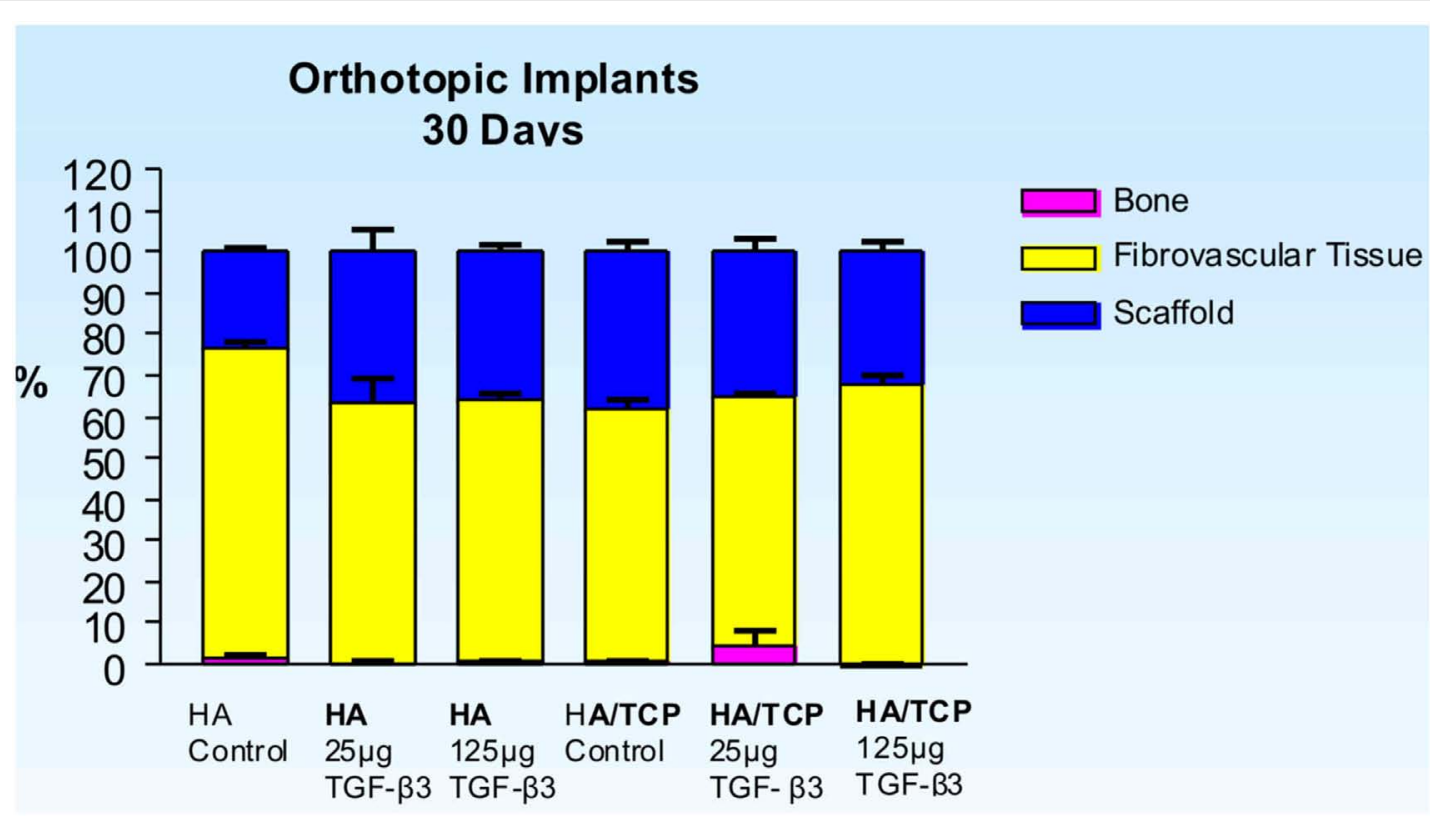

FIGURE 3 | Distribution of newly formed bone, fibrovascular tissue and residual scaffold material in orthotopic implants 30 days after implantation of single phase HA and biphasic HA/ $\beta$-TCP macroporous constructs loaded with 0 (control), 25 and $125 \mu \mathrm{g}$ hTGF- $\beta_{3}$. 

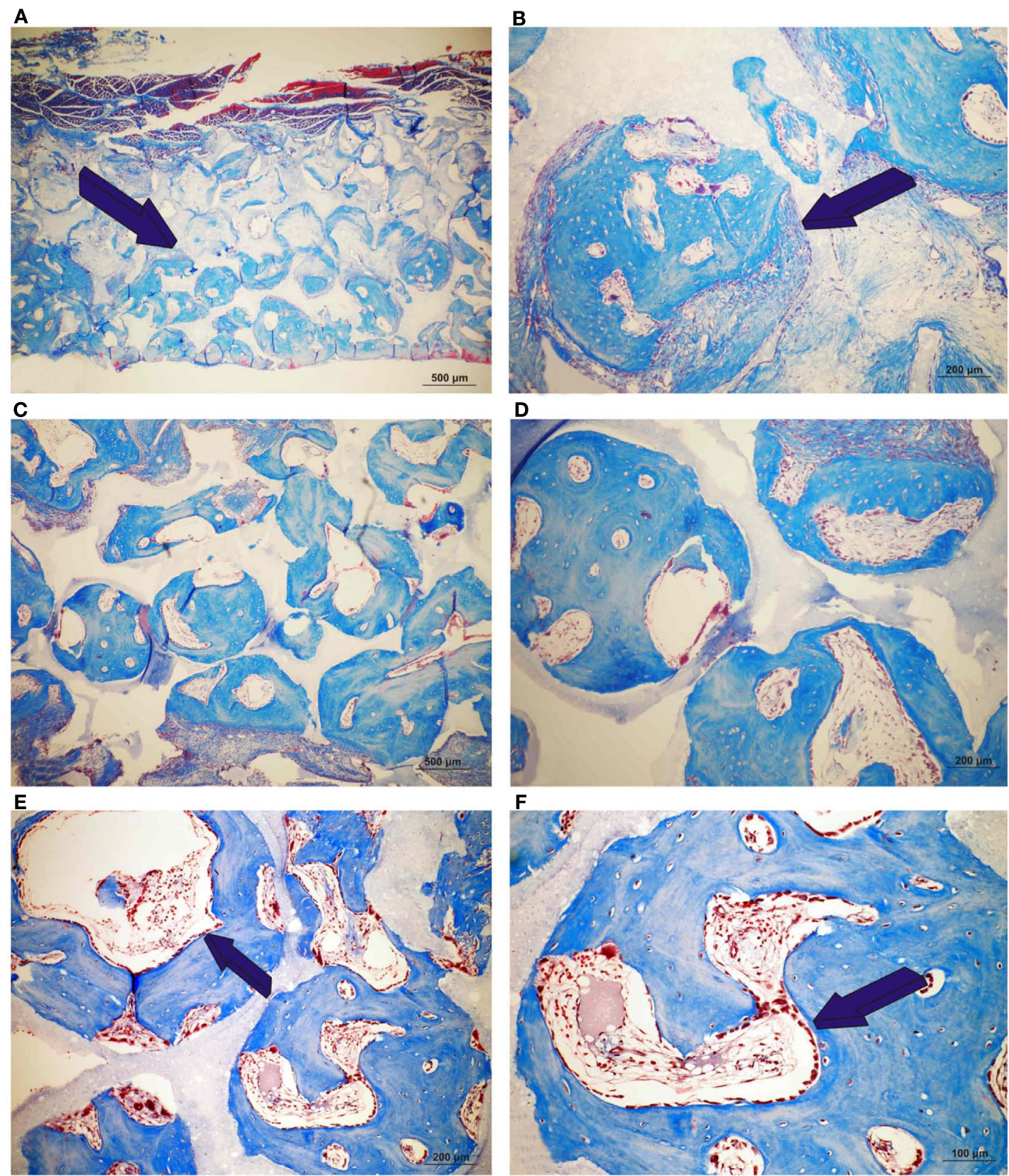

FIGURE 4 | Induction of bone formation by orthotopic calvarial implants of single phase HA harvested on day $\mathbf{9 0}$. (A,B) Low and high power views of untreated single phase HA showing bone formation endocranially (dark blue arrow) (A) and within macroporous space (B). (C,D) Induction of bone

formation across the macroporous spaces by a single phase HA pre-treated with $25 \mu \mathrm{g} \mathrm{hTGF-} \beta_{3}$. (E,F) High power views of macroporous spaces treated with $125 \mu \mathrm{g} \mathrm{hTGF}-\beta_{3}$. Multiple osteoblasts (dark blue arrows) surfacing the newly formed bone.

formed woven bone formed in specimens pre-treated with $25 \mu \mathrm{g}$ TGF- $\beta_{3}(4.68 \pm 3.5 \%)$ Figures $\left.6 \mathrm{E}, \mathbf{F}\right)$, though bone was not detected in specimens pre-treated with $125 \mu \mathrm{g}$ TGF- $\beta_{3}$ (Figure 3).

On day 90, control macroporous biphasic HA/ $\beta$-TCP constructs induced $27.24 \pm 1.27 \%$ bone (Figures 5 and 7 ). The newly formed bone was distributed throughout the macro porous spaces of the specimens. Single phase HA implants showed greater amounts of bone formation when compared to biphasic implants (Figure 5). Biphasic HA/ $\beta$-TCP implants with 25 and $125 \mu \mathrm{g}$ TGF- $\beta_{3}$ induced $33.57 \pm 1.88$ and $27.00 \pm 0.73 \%$ bone, respectively (Figures $\mathbf{5}$ and 8 ). Both types of implants, with or without hTGF- $\beta_{3}$, showed pronounced vascularization and cellular activity, including macrophages and multinucleated cells attached to the implanted matrices. 


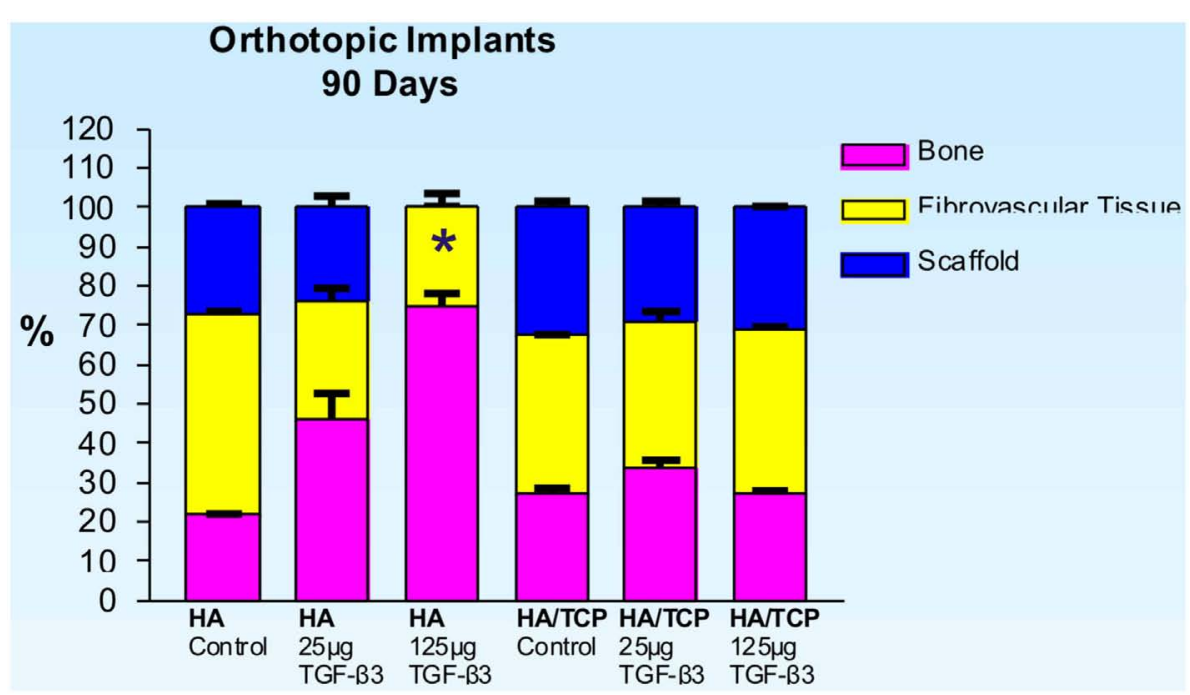

FIGURE 5 | Distribution of newly formed bone, fibrovascular tissue and residual scaffold material in orthotopic implants $\mathbf{9 0}$ days after implantation with 0 (control), 25 and $125 \mu \mathrm{g} \mathrm{hTGF}-\beta_{3}$ in single phase HA and biphasic HA/ $\beta$-TCP macroporous constructs. Significant differences $\left({ }^{*} p<0.01\right)$, as detected by Dunnet's multiple comparison test, were noted for control vs. SPHA treated with $125 \mu \mathrm{g} \mathrm{hTGF}-\beta_{3}$.

\section{Heterotopic implants: rods and disks of sintered macroporous $H A / \beta-T C P-H A 33 \%-30$ and 90 days}

On day 30,25 and $125 \mu \mathrm{g}$ hTGF- $\beta_{3}$-treated macroporous constructs showed prominent vascularization throughout the specimens. Macroporous rods loaded with $125 \mu \mathrm{g}$ hTGF- $\beta_{3}$ resulted in greater bone formation $(19.61 \pm 5.44 \%)$ when compared with the disk-shaped implants (7.96 $\pm 6.39 \%$; Figure 9). Islands of chondrogenesis were seen along the outer rim of the implanted constructs, extending into the porous spaces (not shown). On day 90, newly formed bone was prominently seen surrounding the hTGF$\beta_{3}$-treated matrices extending into the macroporous spaces of both rods and disks. Of note, bone formed predominantly at the periphery of the implanted scaffolds, with minimal bone if any in the center of the pre-loaded constructs (Figure 10). Central macroporous spaces showed lack of bone formation with fibrovascular invasion and multinucleated cells attached to the surface concavities. When evaluated within the macroporous spaces, $125 \mu \mathrm{g}$ hTGF- $\beta_{3}$ resulted in less bone formation (rods: $27.49 \pm 1.07 \%$; disks: $25.00 \pm 1.00 \%$ ) when compared to $25 \mu \mathrm{g}$ hTGF- $\beta_{3}$ (rods: $35.92 \pm 2.42 \%$; disks: $32.25 \pm 2.25 \%$; Figure 11).

\section{Heterotopic implants: fully converted coral-derived HA/CC, 5\% HA/CC, and $13 \%$ HA/CC -20 and 30 days}

Implants treated with 125 and $250 \mu \mathrm{g}$ hTGF- $\beta_{3}$ showed large areas of newly formed bone prominently extending to the periphery of the implanted macroporous constructs with minimal induction of bone within the macroporous spaces of the implanted matrices (Figures 12 and 13). Fully converted macroporous coral-derived constructs showed almost identical results when pre-loaded with 125 or $250 \mu \mathrm{g}$ hTGF- $\beta_{3}(31.68 \pm 1.31$ and $31.27 \pm 0.12 \%$, respectively; Figure 14). 5\% HA/CC implants treated with 125 and $250 \mu \mathrm{g}$ hTGF- $\beta_{3}$ showed a dose-dependent increase of bone formation, $21.47 \pm 1.34$ vs. $33.18 \pm 5.91 \%$, respectively (Figure 14).
Rapid and substantial induction of bone formation had occurred in specimens pre-loaded with $250 \mu \mathrm{g}$ hTGF- $\beta_{3}$. There was extensive spatial/temporal tissue induction and morphogenesis by day 20 with large mineralized ossicles well outside the profile of the implanted matrix with multiple trabeculation of newly formed mineralized bone (Figure 13). Newly formed trabeculae were covered by contiguous rows of well rounded osteoblasts; low power digital images indicated the in vivo rapid induction of large masses of bone (Figure 13) even greater than the previously reported massive induction of the synergistic induction of bone formation at a ratio of 1:20 by weight of hTGF- $\beta_{1}$ and hOP-1, respectively (Ripamonti et al., 1997).

The induction of bone by binary applications of hTGF- $\beta_{3}$ and hOP- 1 at $1: 5$ ratio by weight was greater than the quantity of bone in specimens pre-loaded with the inverse ratio of 5:1. 5\% HA/CC, treated with the $1: 5$ ratio, yielded $38.30 \pm 8.88 \%$ bone compared with $18.23 \pm 8.41 \%$ at the $5: 1$ ratio (Figure 15). Statistically greater amounts of bone $(p<0.05)$, as detected by Bonferroni's multiple comparison test, were generated in $13 \% \mathrm{HA} / \mathrm{CC}$ as compared to $5 \% \mathrm{HA} / \mathrm{CC}$ specimens with the hTGF- $\beta_{3}$ : hOP- 1 at the $1: 5$ ratio than the inverse ratio $(38.51 \pm 3.60$ vs. $7.70 \pm 2.02 \%$, respectively; Figure 15).

\section{DISCUSSION}

Regenerative medicine is the grand multidisciplinary challenge of molecular, cellular, and evolutionary biology requiring the integration of tissue biology, tissue engineering, developmental and experimental surgery to trigger de novo and ex novo induction of tissues and organs of the mammalian body (Sampath and Reddi, 1981, 1983; Khouri et al., 1991; Reddi, 1998, 2000; Viola et al., 2003).

The need for alternatives to recombinant hBMPs/OPs is now felt more acutely after the reported complications and performance failure in clinical contexts (Carragee et al., 2011a,b; Fauber, 
A

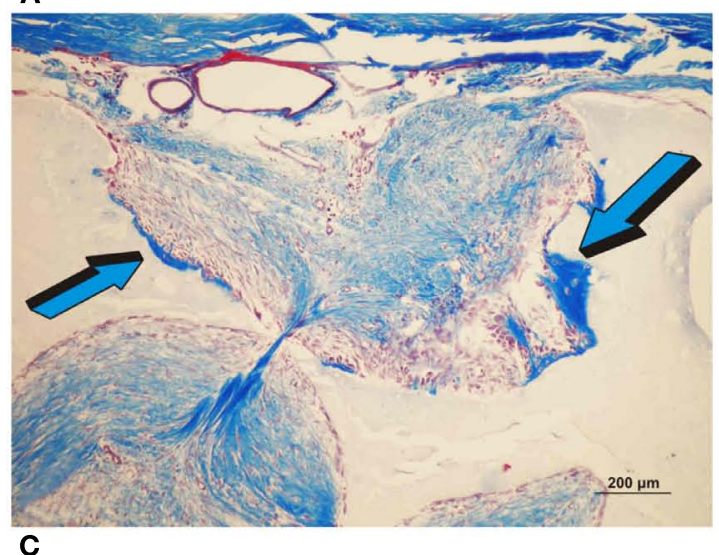

C

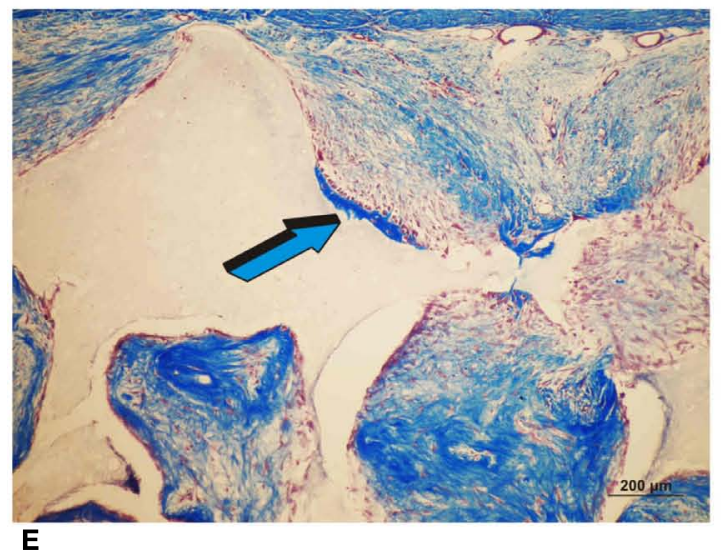

E

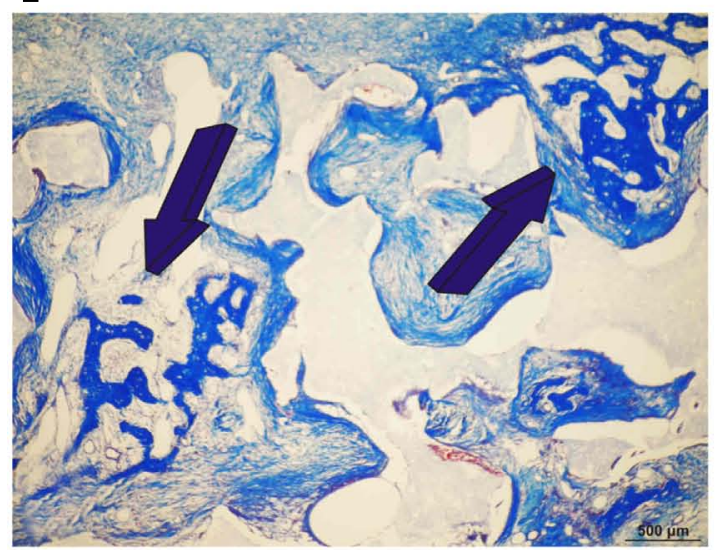

FIGURE 6 | Induction of bone formation by orthotopic calvarial biphasic hydroxyapatite/ $\beta$-tricalcium phosphate (HA/ $\beta$-TCP) harvested on day 30. $(\mathbf{A}, \mathbf{B})$ Low and high power views of untreated $\mathrm{HA} / \beta$-TCP construct showing bone formation pericranially (light blue arrows) (A) within macroporous spaces (A,B). (C,D) Induction of bone formation within concavities (arrows) of
B
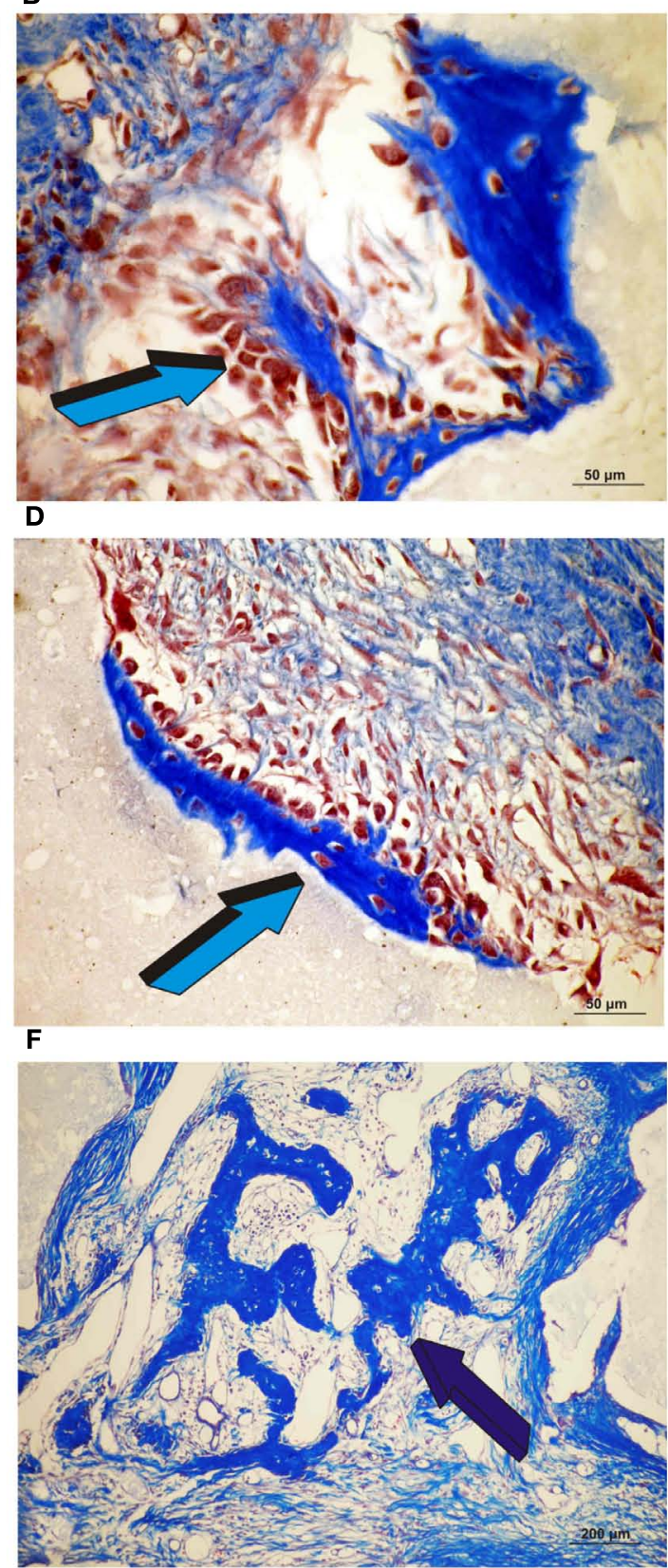

2011b). Contrary to study in rodents and lagomorphs, heterotopic implantation of recombinant hTGF- $\beta_{3}$ reconstituted with insoluble and inactive collagenous bone matrix, induces rapid and substantial bone formation in the non-human primate $P$. ursinus (Ripamonti et al., 2008, 2009a).

We have shown that sintered HA/ $\beta$-TCP and coral-derived macroporous constructs combined with doses of the mammalian the macroporous spaces of untreated $\mathrm{HA} / \beta$-TCP constructs; the induction of bone forms exclusively within the concavities of the implanted substratum (blue arrows) (E,F) High power views of macroporous spaces treated with $125 \mu \mathrm{g} \mathrm{hTGF}-\beta_{3}$ with multiple osteoblasts surfacing the newly formed bone (dark blue arrows).
hTGF- $\beta_{3}$ form a super activated bioreactor inducing rapid and substantial bone formation. Of note, bone had predominantly formed at the periphery of the implanted super activated biomimetic constructs. The peripheral induction of tissue morphogenesis prominently characterized the induction of bone formation by high doses of the recombinant protein. Peripheral tissue induction also characterized coral-derived bioreactors 


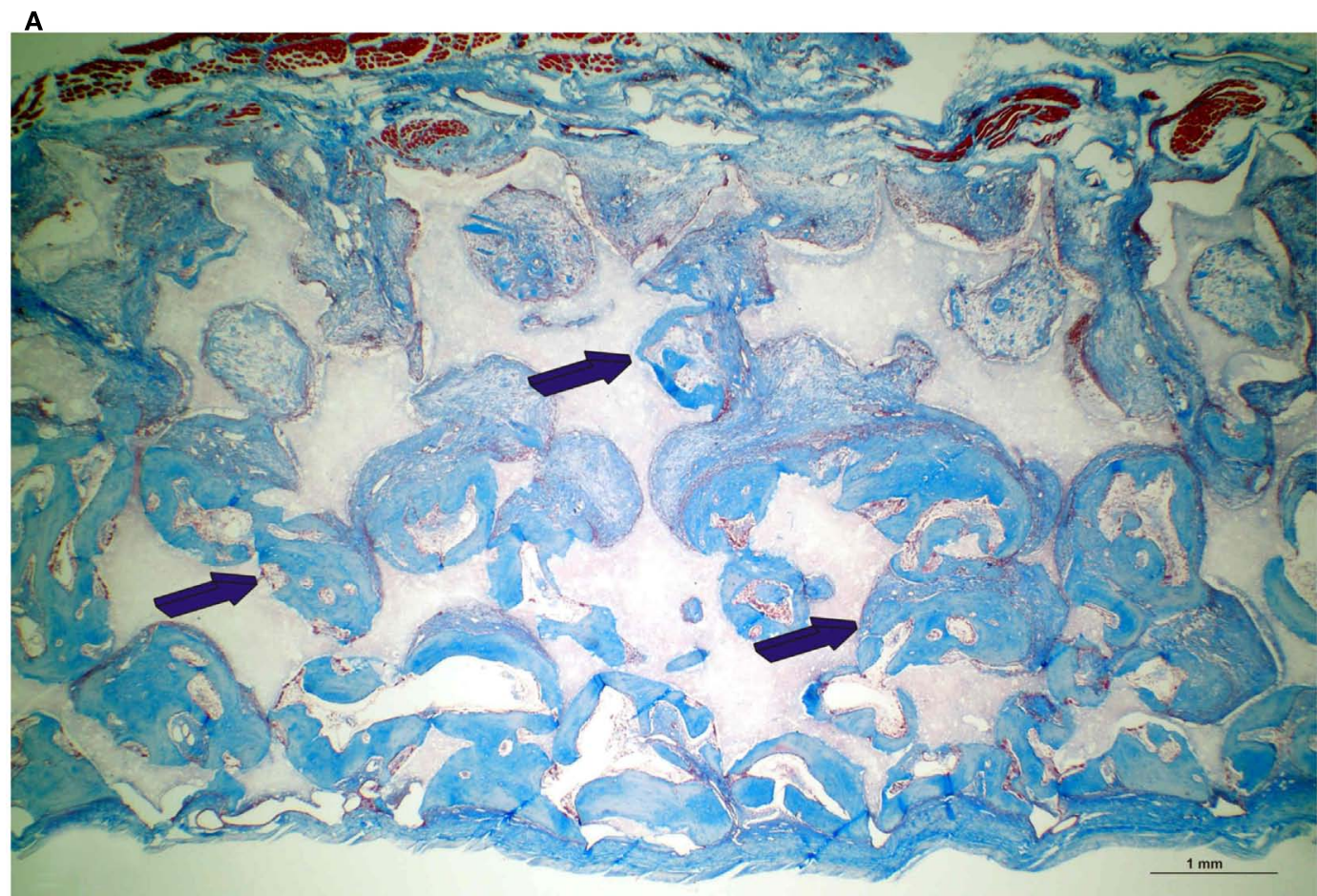

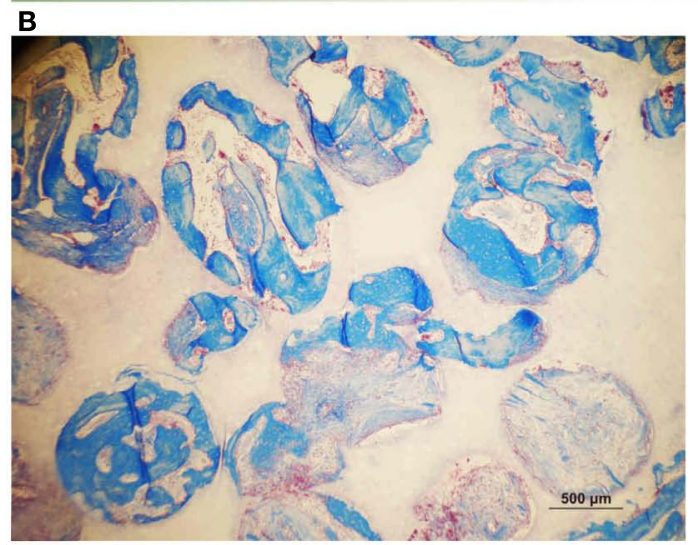

FIGURE 7 | Induction of bone formation by untreated orthotopic calvarial biphasic hydroxyapatite/ $\beta$-tricalcium phosphate (HA/ $\beta$-TCP) harvested on day 90. (A) Low power view showing the induction of

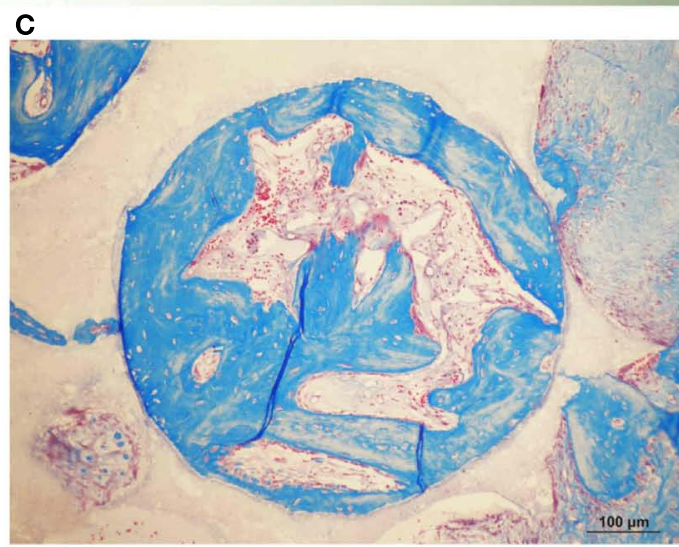

bone formation across the macroporous spaces (dark blue arrows). (B,C) High power views of newly formed bone within macro porosities of the substratum. pre-loaded with binary applications of the recombinant morphogens. Provocatively, binary applications of hOP-1 and hTGF$\beta_{1}$ or platelet-derived TGF- $\beta_{1}$ and hTGF- $\beta_{3}$ synergize to induce massive ossicles in orthotopic calvarial and heterotopic rectus abdominis intramuscular sites (Ripamonti et al., 1997, 2010; Duneas et al., 1998). Of note, the temporal/spatial distribution of bone formation is rapid with the induction of large expanded and corticalized ossicles outgrowing the rectus abdominis intramuscular space and orthotopically, the pericranial calvarial space (Ripamonti et al., 1997, 2010; Duneas et al., 1998).

Responding mesenchymal stem cells, either myoblastic/pericytic of striated muscle or osteoprogenitor pericranial stem cells surrounding the implanted scaffolds, rapidly transform to the synergistic induction of bone formation. TGF- $\beta_{1}$ and TGF- $\beta_{3}$ pre-loaded collagenous bone matrix as carrier singly or in binary application with hOP-1 induce rapid bone formation, with limited if any tissue formation in the central void-like areas of the newly formed ossicles (Ripamonti et al., 1997, 2010; Duneas et al., 1998).

In previous studies using three different doses of the hTGF- $\beta_{1}$ isoform combined with the $25 \mu \mathrm{g}$ selected dose of hOP-1, synergy was found to be optimal at a ratio of 1:20 by weight of hTGF- $\beta_{1}$ :hOP-1, respectively (Ripamonti et al., 1997). We have previously reported that regeneration of cartilage and bone in postnatal life shares common cellular and molecular mechanisms with embryonic bone development, and that the "memory" of 

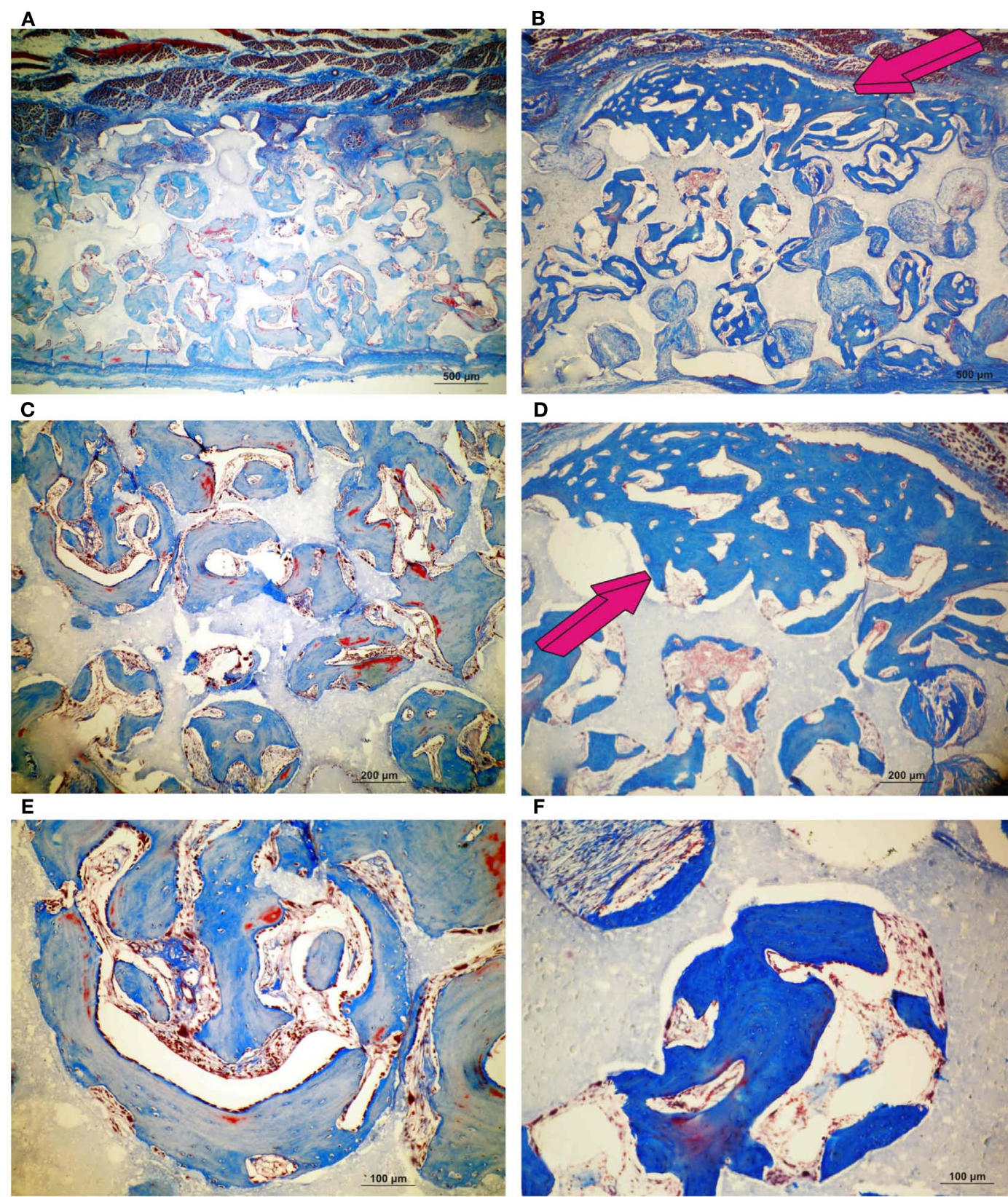

FIGURE 8 | Induction of bone formation by orthotopic calvarial biphasic hydroxyapatite/ $\beta$-tricalcium phosphate (HA/ $\beta$-TCP) pre-treated with $25(A, C, E)$ and $125 \mu \mathrm{g}(B, D, F)$ human recombinant transforming growth factor- $\beta_{3}$ (hTGF- $\beta_{3}$ ) harvested on day $\mathbf{9 0}$.

Induction of bone formation with prominent pericranial osteogenesis (magenta arrows) by $125 \mu \mathrm{g} \mathrm{hTGF-} \beta_{3}$. developmental events in embryo can be redeployed and recapitulated postnatally by the application of morphogens' combination (Ripamonti et al., 1997). Changing the morphogen ratio, as reported in the present experiment, substantially alters the impetus of the morphogenetic cascade; the inversion of hTGF$\beta_{3}$ vs. hOP-1 ratios significantly reduces the induction of bone formation. Synergistic interactions amongst secreted morphogens are a general principle adopted in embryonic development, later invocated in postnatal life. Synergistic synchronous expression of related gene products tightly controlled by threshold levels of finely tuned secreted morphogens, engineers morphogenesis of specialized tissues and organs.

By day 20 , in specimens pre-loaded with $250 \mu \mathrm{g} \mathrm{hTGF}-\beta_{3}$, there was extensive spatial/temporal tissue induction and morphogenesis. Large mineralized ossicles formed well outside the profile of the implanted matrix with multiple trabeculation of newly formed mineralized bone. Newly formed trabeculae were covered by contiguous rows of plump osteoblasts. The rapid induction and 


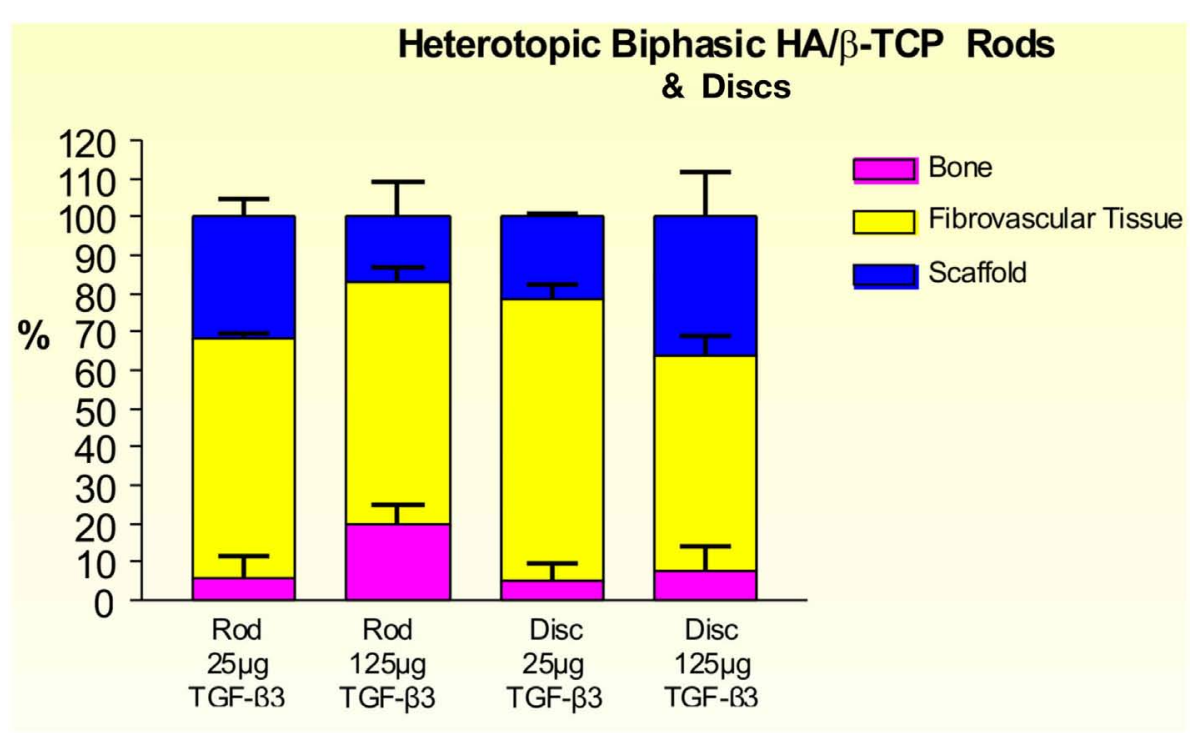

FIGURE 9 | Distribution of newly formed bone, fibrovascular tissue and residual scaffold material in heterotopic implants, 30 days after implantation with 25 and $125 \mu$ h hTGF- $\beta_{3}$, in biphasic HA/ $\beta$-TCP rods and disks.

corticalization of the newly formed heterotopic ossicles is due to the rapid transformation of all available responding stem cells at the periphery of the implanted carriers, either insoluble collagenous bone matrix (Ripamonti et al., 1997; Duneas et al., 1998) or macroporous calcium phosphate-based constructs (Ripamonti et al., 2010), including the present experiments. The recruitment and transformation of all the available responding stem cells at the periphery of the implanted bioactive matrices result in the rapid induction of bone formation outside the profile of the implanted macroporous constructs. The rapid peripheral induction further delays differentiating stem cells migration within the central areas of the macroporous spaces. This results in limited if any bone formation within the center of the implanted macroporous constructs when evaluated on day 30 and 90. Different doses of the hTGF$\beta_{3}$ isoform are responsible for variation in the temporo/spatial induction of bone formation; 250 and $125 \mu \mathrm{g} \mathrm{hTGF}-\beta_{3}$ resulted in greater peripheral induction of bone formation when compared to $25 \mu \mathrm{g} \mathrm{hTGF}-\beta_{3}$ which resulted in greater bone induction within the macroporous spaces owing to the less chemotactic inductive signal of less amounts of the recombinant protein.

High doses of the recombinant morphogen showed the pronounced induction of bone formation well outside the profile of the implanted macroporous scaffolds. The morphological results imply that the ligand attached to the most peripheral regions of the implanted macroporous constructs rapidly sets into motion the ripple-like cascade of bone differentiation. This is potentiated and expanded as a wave throughout the surrounding spaces by the invading rich capillary network with paravascular myoendothelial/pericytic stem cells available for rapid differentiation and transformation toward osteoblastic cell lines under the powerful osteogenic soluble signal of the hTGF- $\beta_{3}$ protein. Indeed the invading rich vascular and paravascular "niches" with accompanying progenitor stem cells (Kovacic and Boehm, 2009) provide stem cells to "feel their way into organogenesis," paraphrasing the concept that cells feel and respond to the stiffness of their substrata (Disher et al., 2005).

The extensive osteoinduction could also be explained by desorption of the morphogen from the implanted macroporous constructs. Desorption as suggested in previous experiments in the primate after the generation of large islands of heterotopic ossification away from the implanted collagenous matrix as carrier (Ripamonti et al., 1996, 2000b). Similarly, desorption of the hTGF$\beta_{3}$ with subsequent diffusion of the recombinant protein within the newly formed highly vascularized matrix including type IV collagen and laminin might have provided an ideal microenvironment for cell differentiation and induction of tissue formation (Trueta, 1963; Reddi, 1984; Duneas et al., 1998). Whether such an extended range of action is due to a diffusion gradient or to the initiation of a sequential chain of cellular induction (Slack, 1987; Lander, 2007) cannot be deduced from the available data.

Of interest, the morphological induction of bone formation by $125 \mu \mathrm{g} \mathrm{hTGF}-\beta_{3}$ is somehow equal when delivered by either insoluble collagenous bone matrix (Figure 10A) or macroporous calcium phosphate-based constructs (Figure 10B), i.e., well enlarged ossicles forming outside the profile of the implanted matrix prominently growing between the ventral fascia and the muscular tissue of the rectus abdominis muscle. This suggests that the biological activity of $125 \mu \mathrm{g}$ hTGF- $\beta_{3}$ is not best delivered by either collagenous matrix or coral-derived macroporous constructs; Figures 12 and 13 clearly indicate that the delivery system for the hTGF- $\beta_{3}$ isoform needs to contend with the most powerful chemotactic and inductive activities inherent to the third mammalian TGF- $\beta$ isoform, which rapidly induces large amount of bone spatially away from the site of the implanted morphogen.

Hyper cellular osteoblastic activity, osteoid synthesis, angiogenesis, and capillary sprouting characterize the newly formed 
A
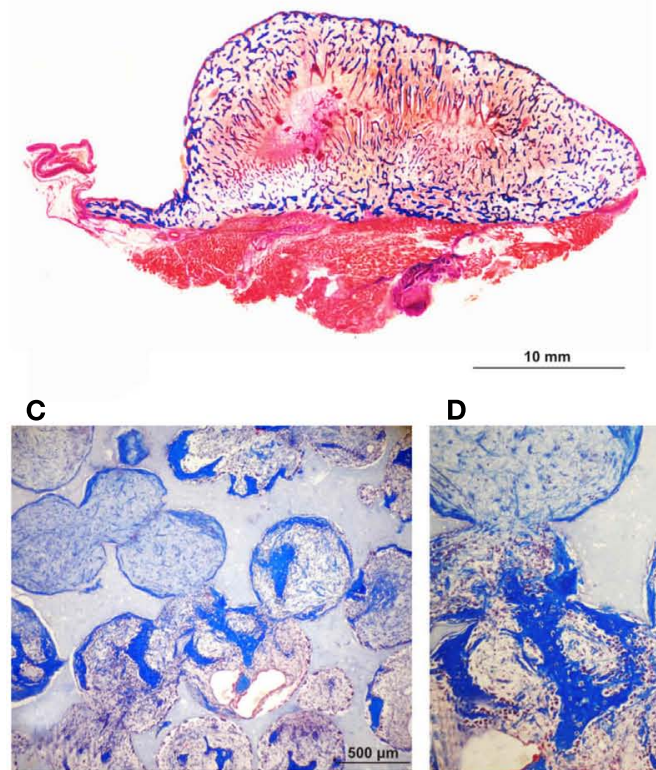

B
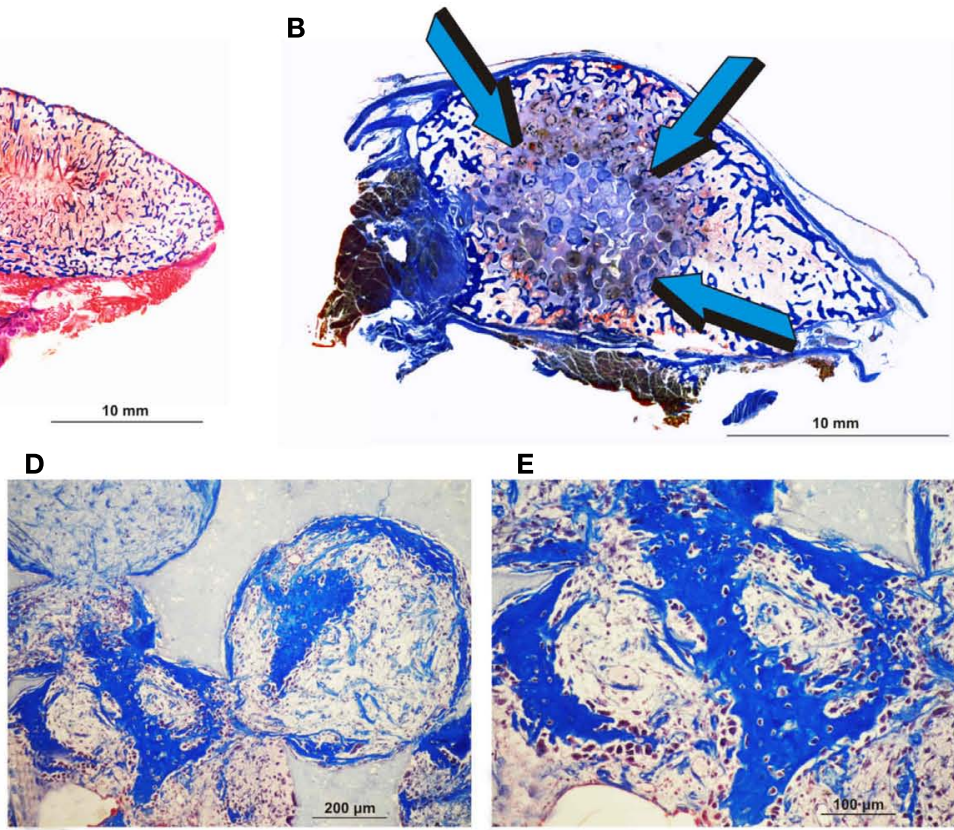

E

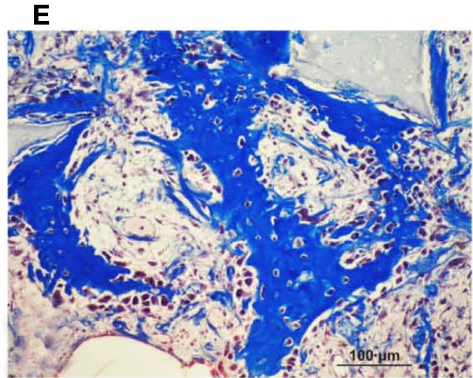

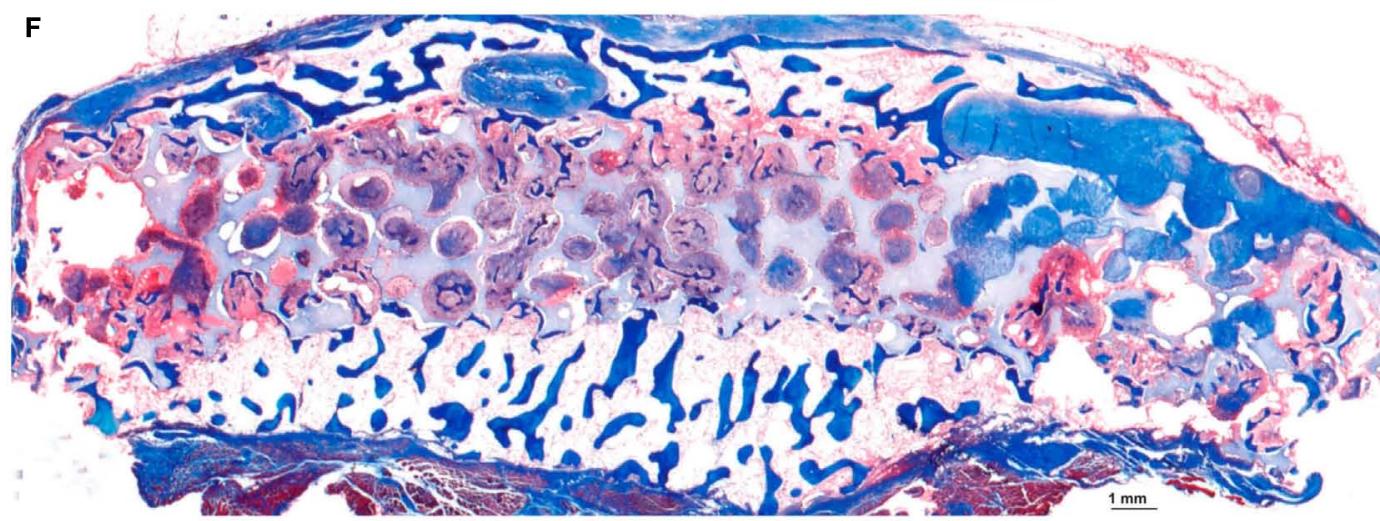

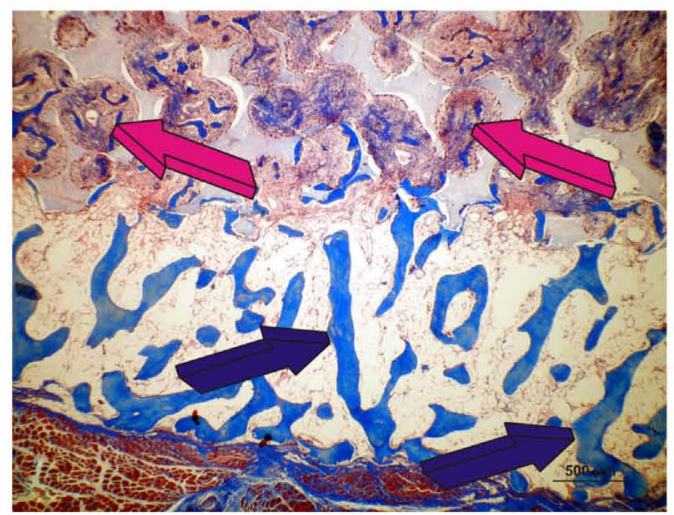

H

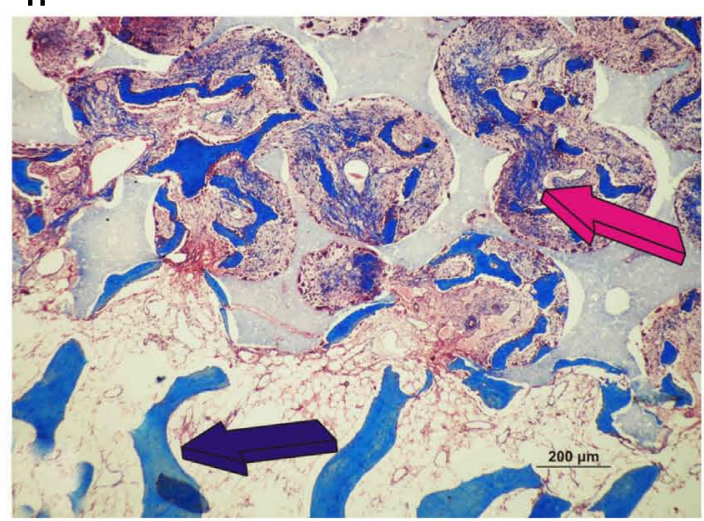

FIGURE 10 | Morphological induction of bone formation by the human recombinant transforming growth factor- $\beta_{3}\left(\mathrm{hTGF}-\beta_{3}\right)$ irrespective of the matrix carrier used as delivery system. Equivalence of the generated constructs either by insoluble collagenous bone matrix (Ripamonti et al. 2008) (A) or macroporous biphasic hydroxyapatite/ $\beta$-tricalcium phosphate (HA/ $\beta$-TCP) (B) with bone formation prominently expanding outside the profile of the implanted macroporous cylinder (blue arrows) pre-treated with $25 \mu \mathrm{g}$ hTGF- $\beta_{3}$. Enlarged ossicles extending within the rectus abdominis muscle generated by either $125 \mu \mathrm{g}$ hTGF- $\beta 3$ (A) or $25 \mu \mathrm{g} \mathrm{hTGF}-\beta_{3}$ (B). (C-E) High power views of newly induced bone by $25 \mu \mathrm{g} \mathrm{hTGF} \beta_{3}$ within the macro porosity of the implanted substratum. (F) Disk of biphasic HA/ $\beta$-TCP construct delivering $25 \mu \mathrm{g} \mathrm{hTGF}-\beta_{3}$ with hypercellular activity within the macro porous spaces. $(\mathbf{G}, \mathbf{H})$ High power views showing transitional morphological features from the peripheral remodeled trabeculation (blue arrows) to a more cellular/woven bone-like induction progressing toward the center of the macroporous construct (magenta arrows). 


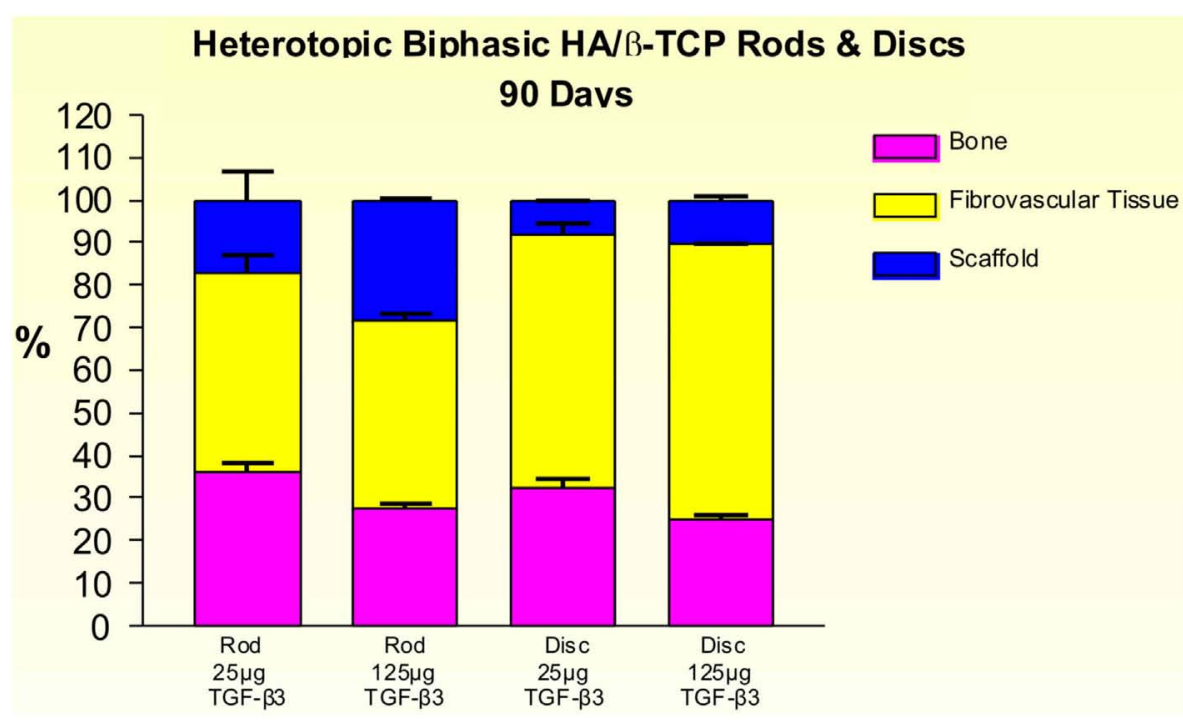

FIGURE 11 | Distribution of newly formed bone, fibrovascular tissue and residual scaffold material in heterotopic implants, 90 days after implantation of biphasic hydroxyapatite/ $\beta$-tricalcium phosphate (HA/ $\beta-\mathrm{TCP}$ ) rods and disks pre-loaded with 25 and $125 \mu \mathrm{g} \mathrm{hTGF-} \beta_{3}$. heterotopic ossicles by the hTGF- $\beta_{3}$ isoform (Ripamonti et al., 2008). Together with the induction of prominent osteogenesis with mineralization in mandibular defects of P. ursinus (Ripamonti, 2006b), the induction of large corticalized mineralized ossicles in the rectus abdominis muscle with large void-like spaces within the newly generated tissues (Ripamonti et al., 2008, 2009a), has suggested that the hTGF- $\beta_{3}$ isoform is the most powerful osteogenic gene product so far tested in non-human primates. It is likely that the associated expression of osteogenic gene products upon the implantation of the mammalian TGF- $\beta$ isoforms particularly type IV collagen mRNA (Duneas et al., 1998) further enhances the bone induction cascade (Ripamonti et al., 1997, 2000a, 2008; Ripamonti and Roden, 2010). The temporal window during which TGF- $\beta_{1}$ mRNA is expressed upon implantation of doses of hOP-1 both heterotopically and orthotopically in P. ursinus is mandatory for the induction of optimal osteogenesis (Ripamonti, 2005). This has been unambiguously demonstrated by the endochondral osteoinductivity of the mammalian TGF- $\beta$ isoforms in nonhuman primates (Ripamonti et al., 1997, 2000b, 2008; Ripamonti and Roden, 2010). We have previously indicated that the hTGF$\beta_{3}$ isoform may regulate the expression of the homologous but molecularly different BMPs/OPs, acting upstream of the bone morphogenetic proteins which may initiate the induction of bone formation (Ripamonti et al., 2008; Ripamonti and Roden, 2010).

Regenerative medicine in clinical contexts is on a different scale altogether when compared to animal models that may not adequately translate and reproduce morphogen-related therapeutic responses in Homo sapiens. Tissue engineering is a field of tremendous promises particularly after successful pre-clinical studies including non-human primate species (Ripamonti et al., 2001, 2006, 2007a). Importantly however novel methods and procedures dramatically shown in animal models have not yet been translated in clinical contexts (Ripamonti et al., 2006, 2007a; Garrison et al., 2007; Mussano et al., 2007). In spite predictions to the contrary
(O'Keefe and Mao, 2011), ultimately it is still doubtful whether tissue engineering will emerge as a winning medical technology or abruptly fail (Williams, 2006).

Presently, the use of recombinant hBMP-2 and hOP-1 in clinical contexts is in the balance (US Food and Drug Administration, 2008; Department of Justice, 2009; Williams et al., 2010; Centre for Devices and Radiological Health, 2011; Fauber, 2011a,b), and the US suppliers for both proteins are currently under US federal and FDA investigations. The recombinant proteins are now no longer available for use in clinical contexts (US Food and Drug Administration, 2008; Department of Justice, 2009; Williams et al., 2010; Centre for Devices and Radiological Health, 2011; Fauber, 2011a). The possible association of high doses of hBMP-2 with malignancies is now additionally under scrutiny (Fauber, 2011a). There is an acute need for morphogen-related bone tissue engineering particularly after the current FDA investigations into hOP-1 and hBMP-2 (US Food and Drug Administration, 2008; Department of Justice, 2009; Williams et al., 2010; Centre for Devices and Radiological Health, 2011; Fauber, 2011a). To establish a robust method to engineer a calcium phosphate-based bone bioreactor for heterotopic induction of bone formation, macroporous calcium phosphatebased constructs were implanted with relatively high doses of the hTGF- $\beta_{3}$ isoform in heterotopic sites of the rectus abdominis muscle in $P$. ursinus. The addition of the hTGF- $\beta_{3}$ isoform constructed a bone bioreactor that enabled the rapid formation of heterotopically induced ossicles with significant induction of bone formation outside the profile of the implanted biomimetic matrices.

\section{CONCLUSION}

Orthotopic applications of hTGF- $\beta_{3}$ induced statistically significant larger volumes of bone at 90 days when loaded onto macroporous single-phase hydroxyapatites as compared to biphasic HA/TCP constructs. Binary applications of hTGF- $\beta_{3}$ and hOP-1 on coral-derived HA/CC macroporous carriers in heterotopic sites 

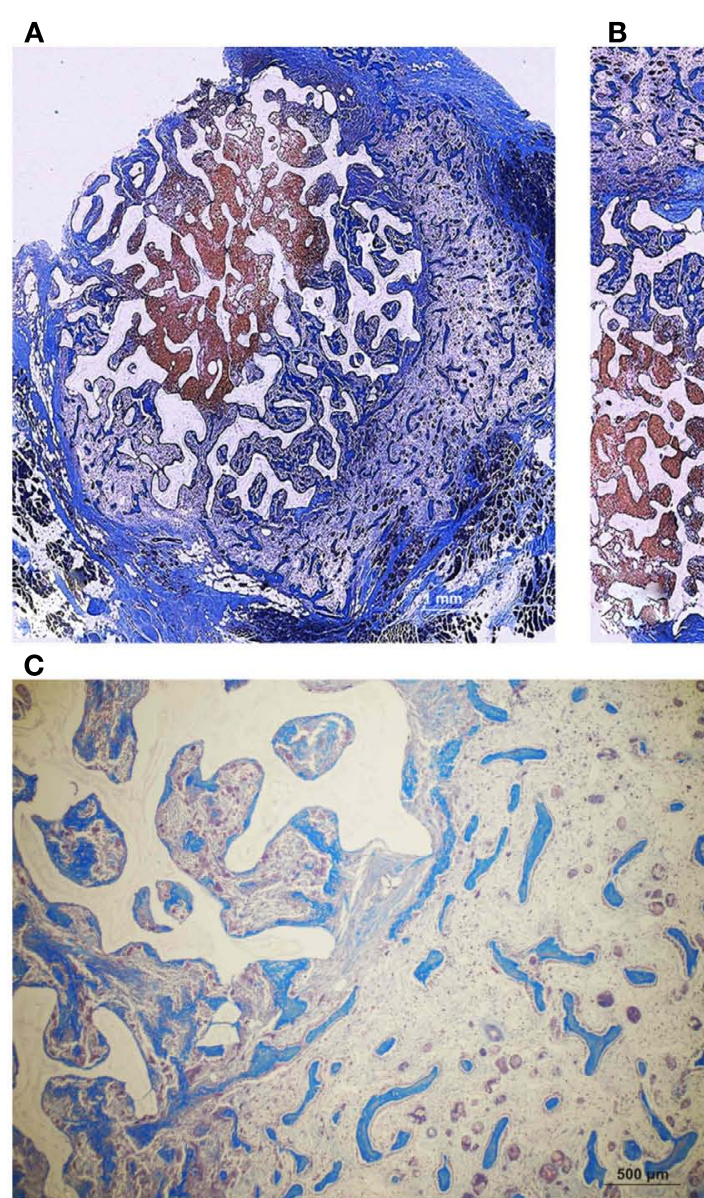

E

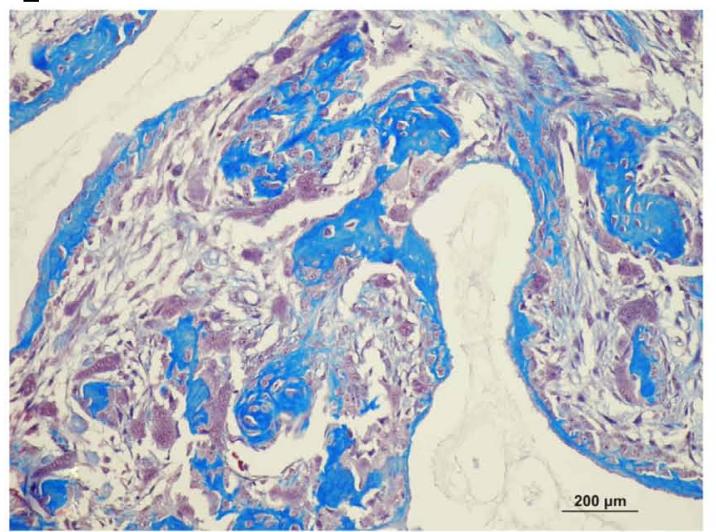

B

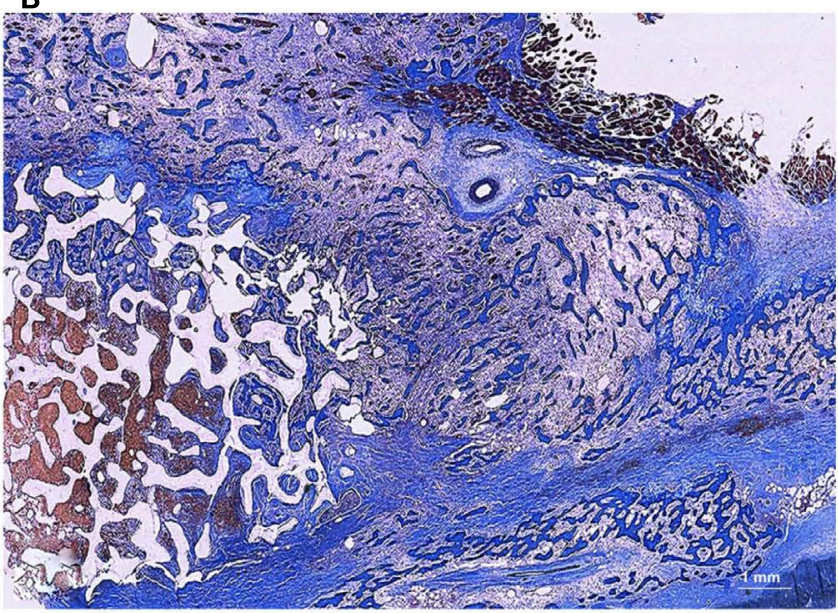

D

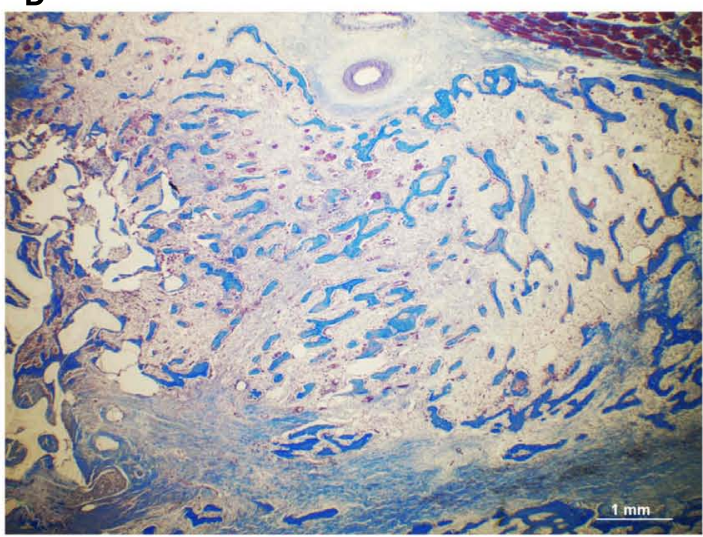

$\mathbf{F}$

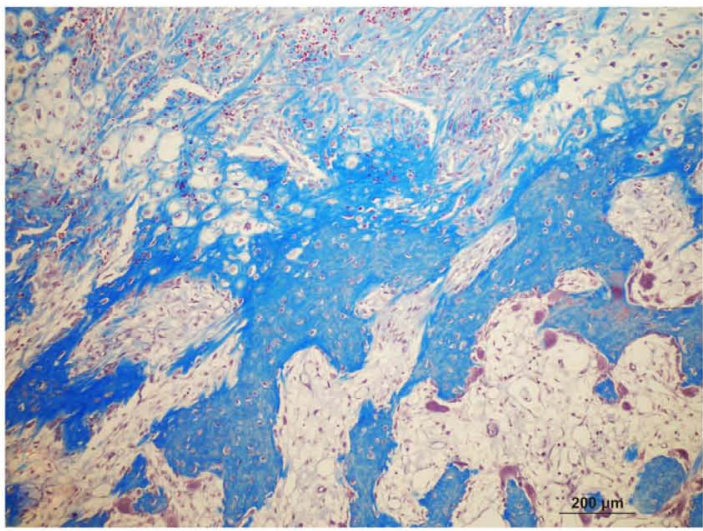

FIGURE 12 | Fully converted coral-derived calcium carbonate constructs $(100 \% \mathrm{HA} / \mathrm{CC})$ pre-treated with $125 \mu \mathrm{g}$ human recombinant transforming growth factor $\beta_{3}$ (hTGF- $\beta_{3}$ ), implanted in the rectus abdominis muscle of Papio ursinus and harvested on day 20 after heterotopic implantation. $(\mathbf{A}, \mathbf{B})$ Induction of bone formation by the
hTGF- $\beta_{3}$ isoform with substantial bone forming outside the macroporous construct prominently extending within the rectus abdominis muscle. (C-F) High power views showing multiple woven bone trabeculation covered by contiguous osteoblasts across the rectus abdominis muscle (D) with bone extending within the macro porous spaces. produced larger amounts of bone at a ratio of 1:5 than the inverse ration in both 5 and $13 \%$ conversions' specimens. The prominent induction of bone formation by $250 \mu \mathrm{g}$ hTGF- $\beta_{3}$ has been translated in clinical contexts to treat a large mandibular defect in a pediatric patient (Ripamonti and Ferretti, 2012). Long term follow up will confirm whether these early results will translate into a complete reconstruction of the avulsed mandibular segment, and to confirm that the implanted $250 \mu \mathrm{g}$ hTGF- $\beta_{3}$ per gram of demineralized human bone matrix is the novel dose required for bone tissue regeneration in clinical contexts. 


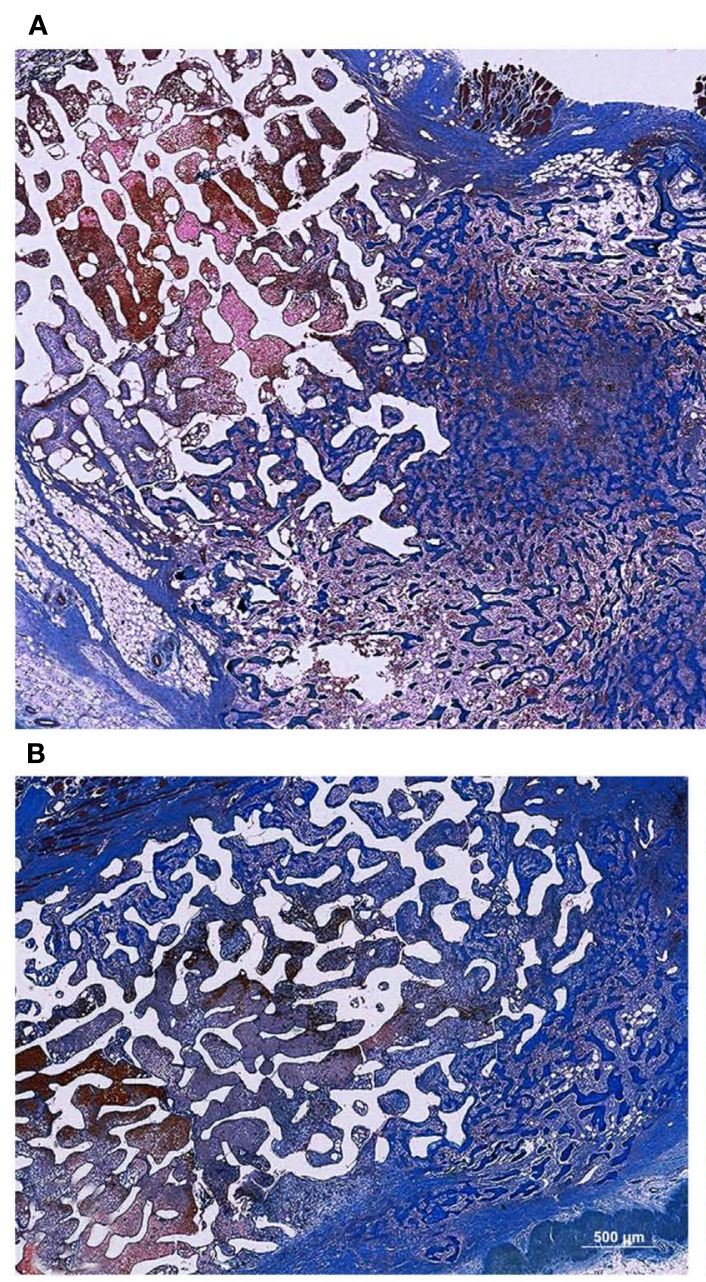

D

C
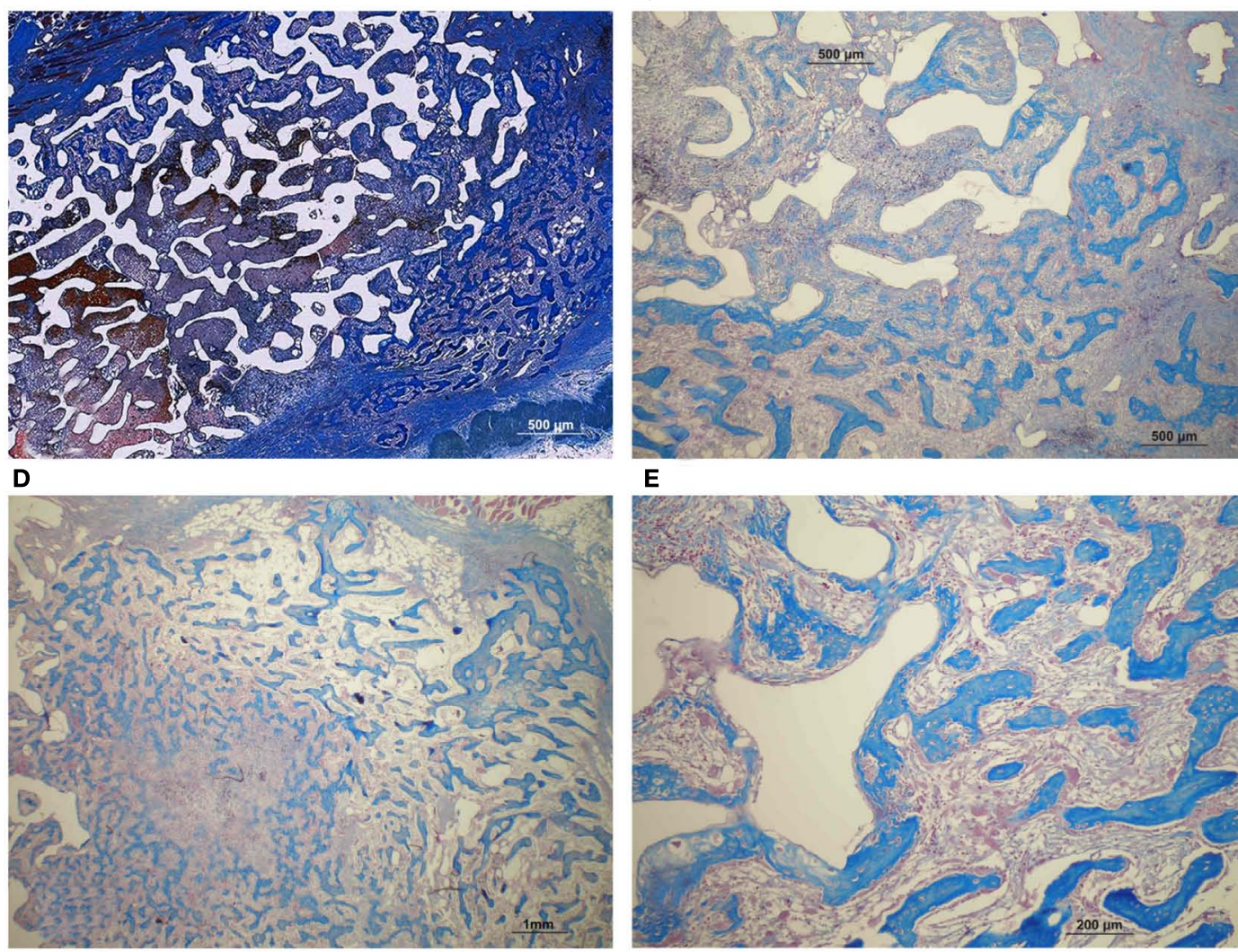

E

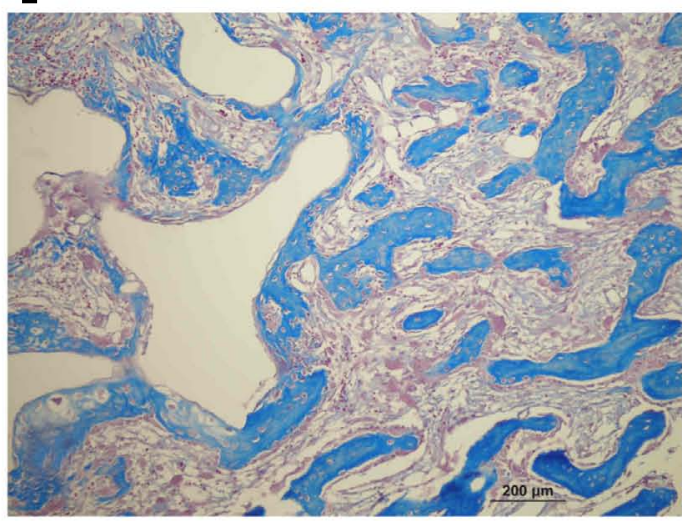

FIGURE 13 | Significant as yet unreported prominent osteogenesis predominantly localized outside the profile of the implanted coral-derived partially converted $5 \%$ HA/CC macroporous construct (A) pre-treated with $250 \mu \mathrm{g}$ recombinant transforming growth factor- $\beta_{3}$ (hTGF- $\beta_{3}$ ) extending within the rectus abdominis muscle 20 days after heterotopic implantation. (D) Middle-power view showing the rapid expansion of the newly formed bone within the rectus abdominis muscle by $250 \mu \mathrm{g} \mathrm{hTGF}-\beta_{3}$. (B) Partially converted $13 \% \mathrm{HA} / \mathrm{CC}$ macroporous construct pre-treated with $125 \mu \mathrm{g} \mathrm{hTGF}-\beta_{3}$ showing the induction of bone formation outside the implanted macroporous construct $(\mathbf{C}, \mathbf{E})$. Middle-power views showing multiple trabeculation of newly formed woven bone also invading the macroporous spaces.

\section{ACKNOWLEDGMENTS}

Supported by grants of the South African Medical Research Council, the University of the Witwatersrand, Johannesburg, and the National Research Foundation. We thank Novartis AG Basel for the supply of human recombinant transforming growth factor- $\beta_{3}$, Creative Biomolecules/Stryker Biotech 


\section{HA/CC Heterotopic Specimens \\ 20 Davs}

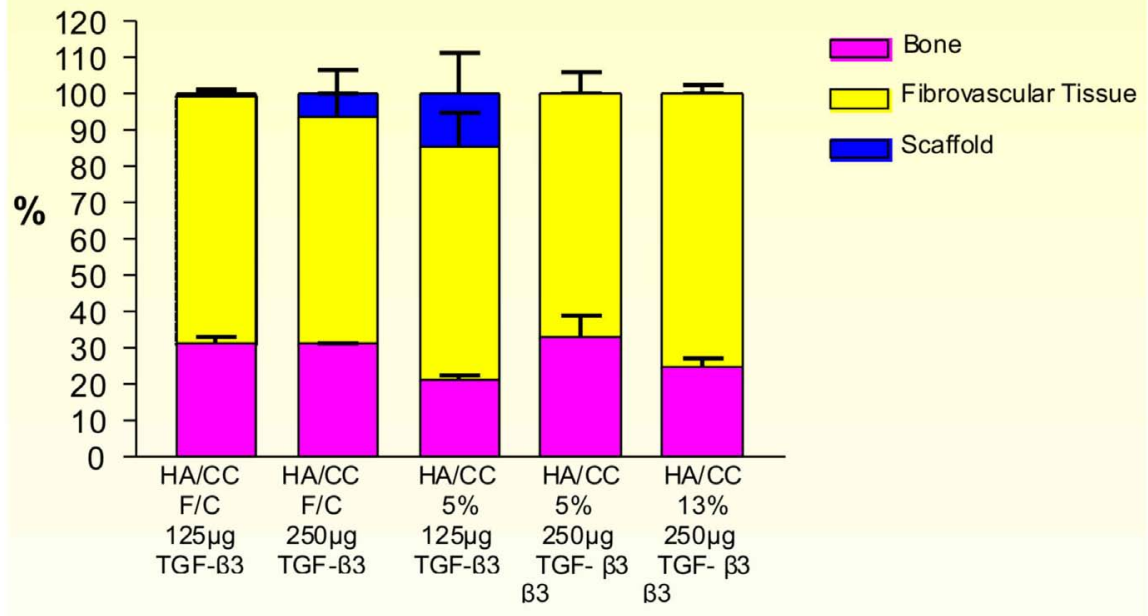

FIGURE 14 | Distribution of newly formed bone, fibrovascular tissue and residual scaffold material in heterotopic implants, 20 days after implantation with 125 and $250 \mu \mathrm{g} \mathrm{hTGF-} \beta_{3}$, in coral-derived hydroxyapatite/calcium carbonate (HA/CC) fully converted (F/C), 5 and $13 \%$ conversion.

\section{HA/CC Binary Application (hTGF- $\beta 3 /$ hOP-1) Heterotopic Specimens \\ 30 Days}
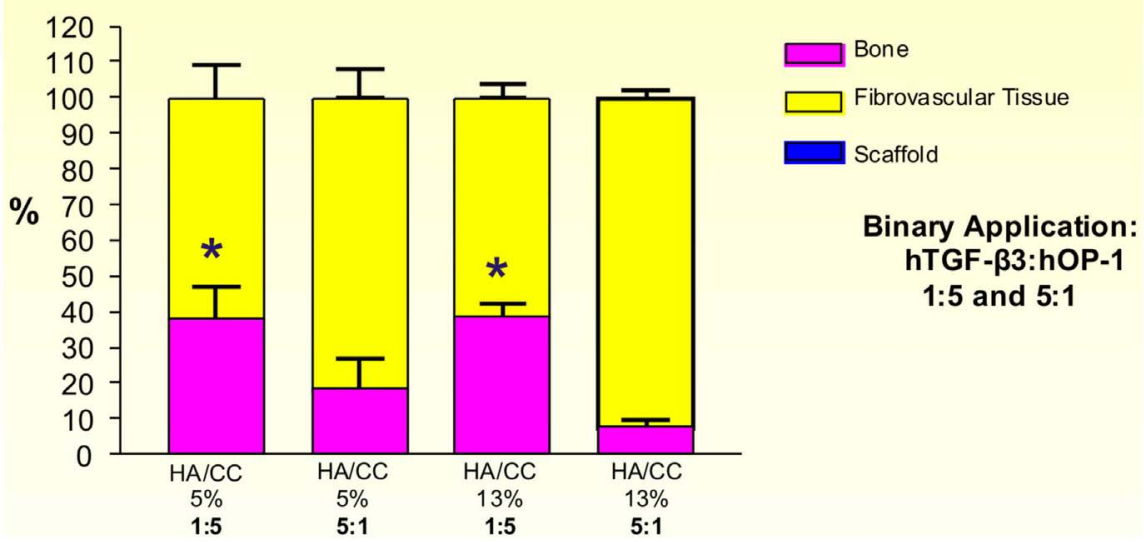

FIGURE 15 | Distribution of newly formed bone, fibrovascular tissue and residual hydroxyapatite/calcium carbonate (HA/CC) material in heterotopic implants, 30 days after implantation with binary application of hTGF- $\beta_{3}$ : hOP-1 at 1:5 and 5:1 ratio by weight in coral-derived HA/CC implants with $\mathbf{5}$ and $\mathbf{1 3} \%$ conversion. Significant differences $(p<0.05)$, as detected by Bonferroni's multiple comparison test, were noted for HACC $5 \%+$ hTGF- $\beta_{3}:$ OP-1 (1:5) and HACC $13 \%+$ hTGF- $\beta_{3}:$ OP-1 (1:5) compared to the inverse ratio $(5: 1)$.

for recombinant human osteogenic protein-1, the CSIR Pretoria Materials Science and Manufacturing for the preparation of single phase and biphasic macroporous constructs,

\section{REFERENCES}

Carragee, E. J., Ghanayem, A. J., Weiner, B. K., Rothman, D. J., and Bono, C. M. (2011a). A challenge to integrity in spine publications: years of living dangerously with the promotion of bone growth factors. Spine J. 11, 463-468.

Carragee, E. J., Hurwitz, E. L., and Weiner, B. K. (2011b). A critical review of recombinant human bone morphogenetic protein-2 trials in spinal surgery:

Mike Ponticiello of Interpore/Biomet USA for providing the coral-derived hydroxyapatite/calcium carbonate constructs.

emerging safety concerns and lessons learned. Spine J. 11, 471-491.

Centre for Devices and Radiological Health. (2011). Public Health Notifications (Medical Devices) FDA Public Health Notification:
Life Threatening Complications Associated with Recombinant Human Bone Morphogenetic Protein in Cervical Spine Fusion. Available at: http:// www.fda.gov/MedicalDevices/Safety/ AlertsandNotices/PublicHealthNotif ications/ucm062000.htm 
Chung, F. H. (1974). Quantitative interpretation of X-ray diffraction patterns, 1. Matrix flushing method of quantitative multicomponent analysis. J. Appl. Crystallogr. 7, 513-519.

Department of Justice. (2009). Acting United States Attorney Michael K. Loucks, District of Massachusetts. Stryker Biotech and its Top Management Indicated for Illegal Promotion of Medical Devices Used in Invasive Surgeries. Available at: http://www.usdoj.gov/usao/ma

Discher, D. E., Janmey, P., and Wang, Y. L. (2005). Tissue cells feel and respond to the stiffnes of their substrate. Science 310, 1139-1143.

Duneas, N., Crooks, J., and Ripamonti, U. (1998). Transforming growth factor- $\beta_{1}$ : induction of bone morphogenetic protein genes expression during endochondral bone formation in the baboon, and synergistic interaction with osteogenic protein-1 (BMP-7). Growth Factors 15, 259-277.

Fauber, J. (2011a). Study Finds Increased Cancer Risk with Bone Growth Product. Journal Sentinel 2011. Available at: http://www. jsonline.com/watchdog/watchdogre ports/study-finds-increased-cancerrisk-with-bone-growth-product-133 208028.html [accessed November. 30, 2011].

Fauber, J. (2011b). Complication from Spinal Product Omitted from Articles: Co-Authors Received Royalties from Manufacturer. Milwaukee J Sentinel 2011. Available at: http:// www.jsonline.com/features/health/ I22553058.html

Friedlaender, G. E., Perry, C. R., Dean Cole, J., Cook, S. D., Cierny, G., Muschler, G. F., Zych, G. A., Calhoun, J. H., Laforte, A. J., and Yin, S. (2001). Osteogenic protein-1 (bone morphogenetic protein-7) in the treatment of tibial nonunions. J. Bone Joint Surg. Am. 83-A, 151-158.

Garrison, K. R., Donell, S., Ryder, J., Shemilt, I., Mugford, M., Harvey, I., and Song, F. (2007). Clinical effectiveness and cost-effectiveness of bone morphogenetic proteins in the non-healing of fractures and spinal fusion: a systematic review. Health Technol. Assess. 11, 1-150, iii-iv.

Govender, S., Csimma, C., Genant, H. K., Valentin-Opran, A., Amit, Y., Arbel, R., Aro, H., Atar, D., Bishay, M., Borner, M. G., Chiron, P., Choong, P., Cinats, J., Courtenay, B., Feibel, R., Geulette, B., Gravel, C., Haas, N., Raschke, M., Hammacher, E., Van Der Velde, D., Hardy, P., Holt, M., Josten, C., Ketterl, R. L., Lindeque, B., Lob, G., Mathevon, H.,
McCoy, G., Marsh, D., Miller, R., Munting, E., Oevre, S., Nordsletten, L., Patel, A., Pohl, A., Rennie, W., Reynders, P., Rommens, P. M., Rondia, J., Rossouw, W. C., Daneel, P. J., Ruff, S., Ruter, A., Santavirta, S., Schildhauer, T. A., Gekle, C., Schnettler, R., Segal, D., Seiler, H., Snowdowne, R. B., Stapert, J., Taglang, G., Verdonk, R., Vogels, L., Weckbach, A., Wentzensen, A., and Wisniewski, T. (2002). Recombinant human bone morphogenetic protein-2 for treatment of open tibial fractures: a prospective, controlled, randomized study of four hundred and fifty patients. J. Bone Joint Surg. Am. 84-A, 2123-2134.

Khouri, R. K., Koudsi, B., and Reddi, H. (1991). Tissue transformation into bone in vivo. a potential practical application. JAMA 266, 1953-1955.

Kovacic, J. C., and Boehm, M. (2009). Resident vascular progenitor cells: an emerging role for non-terminally differentiated vessel-resident cells in vascular biology. Stem Cell Res 2, 2-15.

Lander, A. D. (2007). Morpheus unbound: reimagining the morphogen gradient. Cell 128, 245-256.

Miyazono, K., Kusanagi, K., and Inoue, H. (2001). Divergence and convergence of tgf-beta/bmp signaling. J. Cell. Physiol. 187, 265-276.

Mussano, F., Ciccone, G., Ceccarelli, M., Baldi, I., and Bassi, F. (2007). Bone morphogenetic proteins and bone defects: a systematic review. Spine 32, 824-830.

Nilen, R. W., and Richter, P. W. (2008). The thermal stability of hydroxyapatite in biphasic calcium phosphate ceramics. J. Mater. Sci. Mater. Med. 19, 1693-1702.

O'Keefe, R. J., and Mao, J. (2011). Bone tissue engineering and regeneration: from discovery to the clinic - an overview. Tissue Eng. Part B Rev. 17, 389-392.

Özkaynak, E., Rueger, D. C., Drier, E. A., Corbett, C., Ridge, R. J., Sampath, T. K., and Oppermann, H. (1990). OP1 cdna encodes an osteogenic protein in the TGF- $\beta$ family. EMBO J. 9 , 2085-2093.

Parfitt, A. M. (1983). "Stereologic basis of bone histomorphometry: theory of quantitative microscopy and reconstruction of third dimension," in Bone Histomorphometry: Techniques and Interpretation, ed. H. R. Recker (Boca Raton: CRC Press), 53-87.

Public Services Department. (1990). National Code for Animal Use in Research, Education, Diagnosis, and
Testing of Drugs, and Related Substances in South Africa. Pretoria: Public Services Department.

Reddi, A. H. (1984). "Extracellular matrix and development," in Extracellular Matrix Biochemistry, eds K. A. Piez and A. H. Reddi (New York: Elsevier), 375

Reddi, A. H. (1994). Bone and cartilage differentiation. Curr. Opin. Genet. Dev. 4, 737-744.

Reddi, A. H. (1997). Bone morphogenetic proteins: an unconventional approach to isolation of first mammalian morphogens. Cytokine Growth Factor Rev. 8, 11-20.

Reddi, A. H. (1998). Role of morphogenetic proteins in skeletal tissue engineering and regeneration. Nat. Biotechnol. 16, 247-252.

Reddi,A.H. (2000). Morphogenesis and tissue engineering of bone and cartilage: inductive signals, stem cells, and biomimetic biomaterials. Tissue Eng. 6, 351-359.

Ripamonti, U. (1991a). The morphogenesis of bone in replicas of porous hydroxyapatite obtained from conversion of calcium carbonate exoskeletons of coral. J. Bone Joint Surg. Am. 73, 692-703.

Ripamonti, U. (1991b). Bone induction in nonhuman primates. an experimental study on the baboon. Clin. Orthop. Relat. Res. 269, 284-294.

Ripamonti, U. (2004). Soluble, insoluble and geometric signals sculpt the architecture of mineralized tissues. $J$. Cell Mol. Med. 8, 169-180.

Ripamonti, U. (2005). Bone induction by recombinant human osteogenic protein-1 (hOP-1, BMP-7) in the primate Papio ursinus with expression of mRNA of gene products of the TGF- $\beta$ superfamily. J. Cell Mol. Med. 9, 911-928.

Ripamonti, U. (2006a). Soluble osteogenic molecular signals and the induction of bone formation. Biomaterials 27, 807-822.

Ripamonti, U. (2006b). “The Marshall Urist Awarded Lecture - Bone: formation by autoinduction," in Proceedings of the 6th International Conference on BMP's, 11-16 October 2006, eds S. Vukicevic and A. H. Reddi (Dubrovnick), 1. Available at: http://www.depol.org

Ripamonti, U., Crooks, J., and Kirkbride, A. N. (1999). Sintered porous hydroxyapatites with intrinsic osteoinductive activity: geometric induction of bone formation. $S$. Afr. J. Sci. 95, 335-343.

Ripamonti, U., Crooks, J., Matsaba, T., and Tasker, J. (2000a). Induction of endochondral bone formation by recombinant human transforming growth factor- $\beta_{2}$ in the baboon (Papio ursinus). Growth Factors 17, 269-285.

Ripamonti, U., van den Heever, B. Crooks, J., Tucker, M. M., Sampath, T. K., Rueger, D. C., and Reddi, A. H. (2000b). Long-term evaluation of bone formation by osteogenic protein 1 in the baboon and relative efficacy of bone-derived bone morphogenetic proteins delivered by irradiated xenogeneic collagenous matrices. J. Bone Miner. Res. 15, 1798-1809.

Ripamonti, U., Duneas, N., van den Heever, B., Bosch, C., and Crooks, J. (1997). Recombinant transforming growth factor- $\beta_{1}$ induces endochondral bone in the baboon and synergizes with recombinant osteogenic protein-1 (bone morphogenetic protein-7) to initiate rapid bone formation. J. Bone Miner. Res. 12, 1584-1595.

Ripamonti, U., and Ferretti, C. (2012). "Grand challenges for craniomandibulofacial reconstruction by human recombinant transforming growth fcator- $\beta 3$," in Proceedings of the Keystone Symposia on Regenerative Tissue Engineering and Transplantation, 1-6 April, eds R. S. Tuan, F.Guilak, and A. Atala (Breckenridge, CO: Keystone Symposia Molecular and Cellular Biology). Available at: http://www.keystonesymposia.org

Ripamonti, U., Ferretti, C., and Heliotis, M. (2006). Soluble and insoluble signals and the induction of bone formation: molecular therapeutics recapitulating development. J. Anat. 209, 447-468.

Ripamonti, U., Ferretti, C., Teare, J., and Blann, L. (2009a). Transforming growth factor- $\beta$ isoforms and the induction of bone formation: implications for reconstructive craniofacial surgery. J. Craniofac. Surg. 20, 1544-1555.

Ripamonti, U., Crooks, J., Khoali, L., and Roden, L. (2009b). The induction of bone formation by coral-derived calcium carbonate/hydroxyapatite constructs. Biomaterials 30, 1428-1439.

Ripamonti, U., Heliotis, M., and Ferretti, C. (2007a). Bone morphogenetic proteins and the induction of bone formation: from laboratory to patients. Oral Maxillofac. Surg. Clin. North Am. 19, 575-589, vii.

Ripamonti, U., Richter, P. W., and Thomas, M. E. (2007b). Selfinducing shape memory geometric cues embedded within smart hydroxyapatite-based biomimetic matrices. Plast. Reconstr. Surg. 120, 1796-1807. 
Ripamonti, U., Klar, R. M., Renton, L. F., and Ferretti, C. (2010). Synergistic induction of bone formation by hOP-1, hTGF- $\beta_{3}$ and inhibition by zoledronate in macroporous coralderived hydroxyapatites. Biomaterials 31, 6400-6410.

Ripamonti, U., Ma, S. S., and Reddi, A. H. (1992). Induction of bone in composites of osteogenin and porous hydroxyapatite in baboons. Plast. Reconstr. Surg. 89, 731-739.

Ripamonti, U., Ramoshebi, L. N., Matsaba, T., Tasker, J., Crooks, J., and Teare, J. (2001). Bone induction by BMPs/OPs and related family members in primates. J. Bone Joint Surg. Am. 83-A(Suppl. 1), S116-S127.

Ripamonti, U., Ramoshebi, L. N., Teare, J., Renton, L., and Ferretti, C. (2008). The induction of endochondral bone formation by transforming growth factor- $\beta_{3}$ : experimental studies in the non-human primate Papio ursinus. J. Cell Mol. Med. 12, 1029-1048.

Ripamonti, U., and Roden, L. C. (2010). Induction of bone formation by transforming growth factor- $\beta_{2}$ in the non-human primate Papio ursinus and its modulation by skeletal muscle responding stem cells. Cell Prolif. 43, 207-218.

Ripamonti, U., van den Heever, B., Sampath, T. K., Tucker, M. M., Rueger,
D. C., and Reddi, A. H. (1996). Complete regeneration of bone in the baboon by recombinant human osteogenic protein-1 (hOP-1, bone morphogenetic protein-7). Growth Factors 13, 273-289.

Ripamonti, U., van den Heever, B., and Van Wyk, J. (1993). Expression of the osteogenic phenotype in porous hydroxyapatite implanted extraskeletally in baboons. Matrix 13, 491-502.

Sampath, T. K., and Reddi, A. H. (1981). Dissociative extraction and reconstitution of extracellular matrix components involved in local bone differentiation. Proc. Natl. Acad. Sci. U.S.A. 78, 7599-7603.

Sampath, T. K., and Reddi, A. H. (1983). Homology of bone-inductive proteins from human, monkey, bovine, and rat extracellular matrix. Proc. Natl. Acad. Sci. U.S.A. 80, 6591-6595.

Schnitzler, C. M., Ripamonti, U., and Mesquita, J. M. (1993). Histomorphometry of iliac crest trabecular bone in adult male baboons in captivity. Calcif. Tissue Int. 52, 447-454.

Shors, E. C. (1999). Coralline bone graft substitutes. Orthop. Clin. North Am. 30, 599-613.

Slack, J. M. W. (1987). Morphogenetic gradients - past and present. Trends Biochem. Sci. 12, 200-204.
Trueta, J. (1963). The role of vessels in osteogenesis. J. Bone Joint Surg. Br. 45B, 402-418.

US Food and Drug Administration. (2008). US Food and Drug Administration Public Health Notification. Life-Threatening Complications Associated with Recombinant Human Bone Morphogenetic Protein in Cervical Spine Fusion. US Food and Drug Administration: 2008. Available at: http://www.fda.gov/cdrh/safety/070 108-rhbmp.html [accessed June 1, 2011].

Viola, J., Lal, B., and Grad, O. (2003). National Science Foundation ABT Report on: The Emergence of Tissue Engineering as a Research Field. Available at: http://www.abta ssoc.org/reports/Emergence_Tissue Engineering_Research.pdf

Williams, B. J., Smith, J. S., Fu, K.M., Hamilton, D. K., Perra, J., Polly, D., Ames, C., Berven, S., Glassman, S., Knapp, R., and Shaffrey, C. (2010). Complications associated with BMP use in 11,933 cases of spinal fusion. Spine J. 10, S98-S99.

Williams, D. F. (2006). "Tissue engineering: the multidisciplinary epitome of hope and despair," in Studies in Multidisciplinarity, eds R. Paton and L. McNamara (Amsterdam: Elsevier BV), 483-524.
Wozney, J. M., Rosen, V., Celeste, A. J., Mitsock, L. M., Whitters, M. J., Kriz, R. W., Hewick, R. M., and Wang, E. A. (1988). Novel regulators of bone formation: molecular clones and activities. Science 242, 1528-1534.

Conflict of Interest Statement: The authors declare that the research was conducted in the absence of any commercial or financial relationships that could be construed as a potential conflict of interest.

Received: 11 January 2012; accepted: 11 May 2012; published online: 07 June 2012.

Citation: Ripamonti U, Teare J and Ferretti C (2012) A macroporous bioreactor super activated by the recombinant human transforming growth factor- $\beta_{3}$. Front. Physio. 3:172. doi: 10.3389/fphys.2012.00172

This article was submitted to Frontiers in Craniofacial Biology, a specialty of Frontiers in Physiology.

Copyright ( 2012 Ripamonti, Teare and Ferretti. This is an open-access article distributed under the terms of the Creative Commons Attribution Non Commercial License, which permits noncommercial use, distribution, and reproduction in other forums, provided the original authors and source are credited. 